\title{
Field-scale simulation of methane emissions from coastal wetlands in China using an improved version of $\mathrm{CH}_{4} \mathrm{MOD}_{\text {wetland }}$
}

\author{
Tingting Li ${ }^{\text {a,* }}$, Baohua Xie ${ }^{\text {b,c,* }}$, Guocheng Wang a ${ }^{\text {, }}$ Wen Zhang ${ }^{\text {a }}$, Qing Zhang ${ }^{\mathrm{a}}$, Timo Vesala ${ }^{\mathrm{d}, \mathrm{e}}$, Maarit Raivonen ${ }^{\mathrm{d}}$ \\ a LAPC, Institute of Atmospheric Physics, Chinese Academy of Sciences, Beijing 100029, PR China

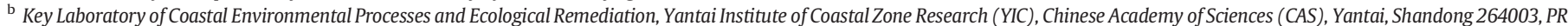 \\ China \\ c Shandong Provincial Key Laboratory of Coastal Environmental Processes, YICCAS, Yantai, Shandong 264003, PR China \\ ${ }^{d}$ Department of Physics, P.O. Box 48, FI-00014, University of Helsinki, Finland \\ e Department of Forest Sciences, P.O. Box 27, FI-00014, University of Helsinki, Finland
}

\section{H I G H L I G H T S}

- Salinity effect on CH4 emissions in coastal wetlands was added into CH4MOD ${ }_{\text {wetland. }}$

- Modeled seasonal CH4 variations corresponded well with observations in tidal marshes.

- Modeled seasonal CH4 emissions agreed well with observations in coastal wetlands.

- The improved model significantly increased model efficiency.

- Previous regional/global CH4 estimations from wetlands may be overestimated.
G R A P H I C A L A B S T R A C T

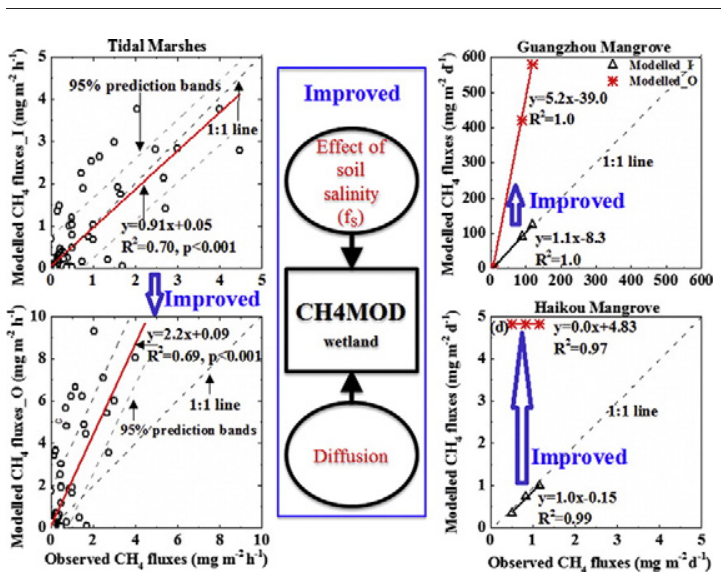

\section{A R T I C L E I N F O}

\section{Article history:}

Received 18 January 2016

Received in revised form 4 March 2016

Accepted 25 March 2016

Available online 8 April 2016

Editor: D. Barcelo

\section{Keywords:}

$\mathrm{CH}_{4}$ emissions

Salinity

Coastal wetlands

$\mathrm{CH}_{4} \mathrm{MOD}_{\text {wetland }}$ model

China

\begin{abstract}
A B S T R A C T
Coastal wetlands are important $\mathrm{CH}_{4}$ sources to the atmosphere. Coastal wetlands account for $\sim 10 \%$ of the total area of natural wetlands in China, but the size of this potential $\mathrm{CH}_{4}$ source remains highly uncertain. We introduced the influence of salinity on $\mathrm{CH}_{4}$ production and $\mathrm{CH}_{4}$ diffusion into a biogeophysical model named $\mathrm{CH}_{4} \mathrm{MOD}_{\text {wetland }}$ so that it can be used in coastal wetlands. The improved model can generally simulate seasonal $\mathrm{CH}_{4}$ variations from tidal marshes dominated by Phragmites and Scirpus. However, the model underestimated winter $\mathrm{CH}_{4}$ fluxes from tidal marshes in the Yellow River Delta and YanCheng Estuary. It also failed to capture the accurate timing of the $\mathrm{CH}_{4}$ peaks in YanCheng Estuary and ChongMing Island in 2012. The improved model could generally simulate the difference between the annual mean $\mathrm{CH}_{4}$ fluxes from mangrove sites in GuangZhou and HaiKou city under different salinity and water table depth conditions, although fluxes were systematically underestimated in the mangrove site of HaiKou city. Using the improved model, the seasonal $\mathrm{CH}_{4}$ emissions simulated across all of the coastal wetlands ranged from 0.1 to $44.90 \mathrm{~g} \mathrm{~m}^{-2}$, with an average value of $7.89 \mathrm{~g} \mathrm{~m}^{-2}$, which is in good agreement with the observed values. The improved model significantly decreased the RMSE and RMD from $424 \%$ to $14 \%$ and $314 \%$ to $-2 \%$, respectively, and improved the $E F$ from -18.30 to 0.99 .
\end{abstract}

\footnotetext{
* Corresponding authors.

E-mail addresses: litingting@mail.iap.ac.cn (T. Li), bhxie@yic.ac.cn (B. Xie).
} 
Model sensitivity analysis showed that $\mathrm{CH}_{4}$ emissions were most sensitive to $P_{o x}$ in the tidal marshes and salinity in the mangroves. The results show that previous studies may have overestimated $\mathrm{CH}_{4}$ emissions on a regional or global scale by neglecting the influence of salinity. In general, the $\mathrm{CH}_{4} \mathrm{MOD}_{\text {wetland }}$ model can simulate seasonal $\mathrm{CH}_{4}$ emissions from different types of coastal wetlands under various conditions. Further improvements of $\mathrm{CH} 4 \mathrm{MOD}$ wetland should include the specific characteristics of $\mathrm{CH}_{4}$ processes in mangroves to decrease the uncertainty in estimating regional or global $\mathrm{CH}_{4}$ emissions from natural wetlands.

(c) 2016 Elsevier B.V. All rights reserved.

\section{Introduction}

Methane $\left(\mathrm{CH}_{4}\right)$ is an important greenhouse gas, with a 100-year global warming potential 25 times stronger than that of carbon dioxide (Lashof and Ahuja, 1990). Methane is responsible for approximately $18 \%$ of human-induced radiative forcing, making it the second most important greenhouse gas after $\mathrm{CO}_{2}$ (Forster et al., 2007). Recently, it was reported that when the indirect global warming effects of $\mathrm{CH}_{4}$ on aerosols and other chemical compounds (e.g., $\mathrm{O}_{3}$ ) was incorporated, previous estimates of the global warming potential of $\mathrm{CH}_{4}$ may be $10-40 \%$ too low (Shindell et al., 2009; IPCC, 2013). Natural wetlands are the single largest natural source of $\mathrm{CH}_{4}$, accounting for approximately one third of total global $\mathrm{CH}_{4}$ emissions, i.e., equivalent to 115 (Fung et al., 1991 ) to $237 \mathrm{Tg} \mathrm{CH}_{4} \mathrm{yr}^{-1}$ (Hein et al., 1997). $\mathrm{CH}_{4}$ emissions from wetlands have been strongly responsive to climate in the past (Chappellaz et al., 1993a,b; Blunier et al., 1995; Loulergue et al., 2008), and will likely continue to be responsive to anthropogenic-driven climate change in the future (Gedney et al., 2004; Eliseev et al., 2008; Ringeval et al., 2011). Moreover, they appear to dominate the interannual variability of the global $\mathrm{CH}_{4}$ source (Bousquet et al., 2006; Ciais et al., 2013). Therefore, increased knowledge of $\mathrm{CH}_{4}$ emissions from natural wetlands is important to understand the global $\mathrm{CH}_{4}$ budget.

Efforts have been made to estimate regional $\mathrm{CH}_{4}$ emissions from natural wetlands by extrapolating field measurements to a given area (Bartlett and Harriss, 1993; Chen et al., 2013; Ding et al., 2004; Seiler and Conrad, 1987). However, this method is unreliable when scaling from site measurements to regional or global scales due to limitations in the spatial and temporal coverage of measurements (Cao et al., 1996). Compared with extrapolation, process-based models are regarded as an improved method for regional estimates because they can describe the processes of $\mathrm{CH}_{4}$ production, oxidation and emission as well as the influence of complex climate, soil, vegetation and hydrology conditions on $\mathrm{CH}_{4}$ emissions (Cao et al., 1996; Li, 2000; Zhang et al., 2002). Some process-based models focus on the $\mathrm{CH}_{4}$ cycling mechanisms and only describe the processes of $\mathrm{CH}_{4}$ production, consumption and transportation under different climatic and soil conditions (e.g., Potter, 1997; Walter and Heimann, 2000; Zhang et al., 2002; Li et al., 2010a). For use at a global scale, some modellers have developed or integrated $\mathrm{a} \mathrm{CH}_{4}$ emission module into a global land ecosystem model (e.g., Zhuang et al., 2004; Xu et al., 2010; Tian et al., 2010; Wania et al., 2010; Riley et al., 2011; Zhu et al., 2014). The popular way of estimating $\mathrm{CH}_{4}$ emissions from natural wetlands is to first calibrate and validate the process-based model at the site-scale, and then upscale the results to a regional or global scale (e.g., Xu and Tian, 2012; Li et al., 2012; Wania et al., 2013; Bohn et al., 2015).

Coastal wetlands are characterized by high temporal and spatial variation related to topographic features, environmental factors and astronomic tidal fluctuation, and are very sensitive to global climate changes and human activities. The global coastal wetland area is $660 \times 10^{3} \mathrm{~km}^{2}$, which accounts for $\sim 10 \%$ of the total wetland area (Lehner and Döll, 2004). Previous studies have shown that coastal wetlands with high salinity usually emit less $\mathrm{CH}_{4}$ than less saline wetlands (Bartlett et al., 1987; Poffenbarger et al., 2011). This has been explained by the presence of sulfate in the sea water, which allows sulfate-reducing bacteria to outcompete methanogens for energy sources, consequently inhibiting methane production (DeLaune et al., 1983; Bartlett et al., 1987; Wang et al., 1996; Poffenbarger et al., 2011). However, most of the above estimates of regional or global $\mathrm{CH}_{4}$ emissions treated the coastal wetlands the same as freshwater wetlands. Moreover, most of the process-based models did not consider the influence of salinity on $\mathrm{CH}_{4}$ fluxes, or these models were not validated at coastal wetland sites.

In China, coastal wetlands accounts for $\sim 10 \%$ of the total area of natural wetlands (Niu et al., 2012). Although there are some sporadic measurements of $\mathrm{CH}_{4}$ emissions from coastal wetlands (e.g., Ye et al., 2000; Huang et al., 2005; Kang et al., 2008; Yang et al., 2007; Yuan et al., 2015), most of the measurements were focused on the freshwater marshes in northeastern China and the Qinghai Tibet Plateau (Song et al., 2007; Ding et al., 2004; Jin et al., 1999; Wei et al., 2015). Moreover, the national $\mathrm{CH}_{4}$ emissions have been estimated to range from 1.7 to $10.5 \mathrm{Tg} \mathrm{yr}^{-1}$, using models or extrapolating measurements to a regional scale, but most of the studies were based on measurements from freshwater wetlands (Wang et al., 1993; Khalil et al., 1993; Jin et al., 1999; Ding et al., 2004; Wang et al., 2012).

Recently, we established a process-based model named

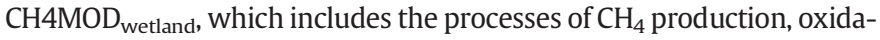
tion and emission (Li et al., 2010a). This model has been validated in various types of freshwater wetlands in China and North America (Li et al., 2010a, 2012). In this study, we integrated a relationship between salinity and $\mathrm{CH}_{4}$ production into $\mathrm{CH} 4 \mathrm{MOD}$ wetland to improve the applicability of the model for use in coastal wetlands. We also compiled a $\mathrm{CH}_{4}$ measurement dataset from latitudinally distributed coastal zone sites using the literature and measurements. The objectives of this study are to modify the $\mathrm{CH}_{4} \mathrm{MOD}_{\text {wetland }}$ model, and to assess the performance of the improved model with respect to $\mathrm{CH}_{4}$ flux estimates by validating the model outputs against measurements collected from coastal wetland sites across different latitudes in China.

\section{Materials and methods}

\subsection{Model overview}

$\mathrm{CH}_{4} \mathrm{MOD}_{\text {wetland }}$ is a biogeophysical process-based model that was developed to describe the processes of $\mathrm{CH}_{4}$ production, oxidation and emission from natural freshwater wetlands (Li et al., 2010a, 2012). This model adopted the hypothesis of the CH4MOD model, which is used to simulate $\mathrm{CH}_{4}$ emissions from rice paddies (Huang et al., 1998). We made modifications based on the supply of methanogenic substrates in natural wetlands, which differs significantly from that in rice paddies. The model inputs include daily air or soil temperature, water table depth, annual net primary productivity (NPP), soil sand fraction, soil organic matter and bulk density. The outputs are daily and annual $\mathrm{CH}_{4}$ production and emissions.

The main processes related to $\mathrm{CH}_{4}$ production, oxidation and emission in $\mathrm{CH}_{4} \mathrm{MOD}_{\text {wetland }}$ are shown in Fig. 1. The methanogenic substrates are derived from root exudates as well as the anaerobic decomposition of plant litter and soil organic matter. In the original model, the environmental factors that influence $\mathrm{CH}_{4}$ production include soil temperature, soil texture and soil redox potential. If the soil temperature was unavailable, we used the air temperature to calculate this variable. The soil redox potential is controlled by the water table depth. In this study, we added the influence of soil salinity on $\mathrm{CH}_{4}$ production to improve the model for use in coastal wetlands. Because the model was formerly used at sites dominated by arenchymous vascular plants, plant-mediated transport is the primary mechanism of $\mathrm{CH}_{4}$ emission. 


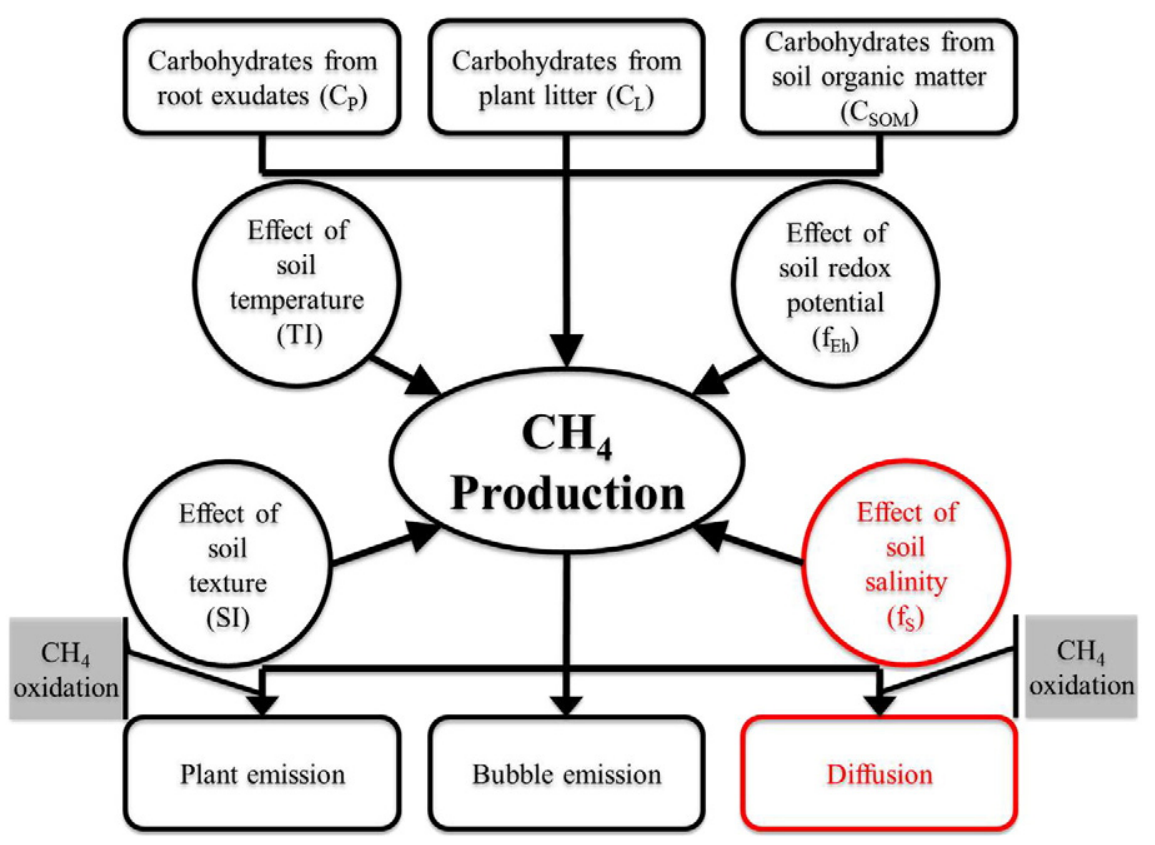

Fig. 1. Conceptual explanation of $\mathrm{CH}_{4} \mathrm{MOD}$ wetland. The red frames are the modification to the model.

$\mathrm{CH}_{4}$ emission via ebullition is significant in the early stages of plant growth. Diffusion was not considered in the original model. In this study, we added the diffusion process of $\mathrm{CH}_{4}$ to ensure that the model can be used at mangrove sites. $\mathrm{CH}_{4}$ oxidation occurs through plant and diffusion transportation.

$\mathrm{CH}_{4} \mathrm{MOD}_{\text {wetland }}$ has been validated against independent field measurements of $\mathrm{CH}_{4}$ fluxes from several types of freshwater wetland sites, including a freshwater marsh in northeastern China, peatland in the Ruoergai Plateau in China, as well as fen in Canada and USA ( $\mathrm{Li}$ et al., 2010a). Additional details on $\mathrm{CH}_{4} \mathrm{MOD}_{\text {wetland }}$ are well documented in previous studies (Li et al., 2010a, 2012, 2015).

\subsection{Model modification}

As shown in Fig. 1, $\mathrm{CH}_{4}$ production is influenced by the soil temperature, soil texture and soil redox potential. When the influence of soil salinity is included, $\mathrm{CH}_{4}$ production is calculated as:

$P=0.27 \times S I \times T I \times F_{E H} \times F_{S} \times\left(C_{P}+C_{L}+C_{S O M}\right)$

where $P$ is $\mathrm{CH}_{4}$ production ( $\mathrm{g} \mathrm{m}^{-2} \mathrm{~d}^{-1}$ ), $C_{P}, C_{L}$ and $C_{S O M}$ are the carbohydrates derived from plant root exudates, plant litter and soil organic matter, respectively; SI, TI, $F_{E H}$ and $F_{S}$ are the influence of soil texture, soil temperature, soil index potential and soil salinity, respectively, on $\mathrm{CH}_{4}$ production; 0.27 is a factor (mole weight basis) to convert carbohydrate into methane.

Previous studies (Atkinson and Hall, 1976; King and Wiebe, 1978; Bartlett et al., 1985; 1987; Magenheimer et al., 1996) indicated that methane emissions from various coastal salt marshes in the temperate zones varied with salinity. This is because electron acceptors such as $\mathrm{NO}_{3}^{-}$and $\mathrm{SO}_{4}^{2-}$ in coastal wetlands can compete with the methanogens for electrons. Poffenbarger et al. (2011) found a significant linear relationship between salinity and log-transformed $\mathrm{CH}_{4}$ from 36 field cases where the salinity ranged from 0.4 to $35.1 \mathrm{ppt}$. In this study, we adopted this relationship and estimated the influence of salinity $F_{S}$ in Eq. (2) as:

$F_{S}=10^{a \times s}$ where $F_{S}$ represents the effect of salinity on $\mathrm{CH}_{4}$ production, $s$ is the salinity (ppt), and $a$ is an empirical constant.

The original version of $\mathrm{CH}_{4} \mathrm{MOD}$ wetland was mainly used to simulate arenchymous vascular plant-dominated sites. At these sites, plantmediated transportation and ebullition contribute $>90 \%$ of $\mathrm{CH}_{4}$ emissions. However, if the model is applied at a wetland site without arenchymous vascular plants, e.g., a mangrove site, diffusion cannot be neglected. This is because compared with vascular plants, woody plants are poor transporters of $\mathrm{CH}_{4}$ (Hook et al., 1971; Grosse et al., 1992; Walter et al., 1996; Walter and Heimann, 2000). We adopted the DLEM equation (Xu et al., 2010; Tian et al., 2010) to calculate the $\mathrm{CH}_{4}$ diffusion rate:

$E_{D}=R \times\left(P \times h-P_{\max }\right) \times f_{\text {oxi }}$

where $E_{D}$ is the $\mathrm{CH}_{4}$ emission rate via diffusion $\left(\mathrm{g} \mathrm{m}^{-2} \mathrm{~d}^{-1}\right)$, $P$ is methane production in Eq. (1) $\left(\mathrm{g} \mathrm{m}^{-2} \mathrm{~d}^{-1}\right), h$ is the soil depth, for which we used $0.5 \mathrm{~m}$ in this study, $P_{\max }$ is the critical value at which diffusion occurs (Xu et al., 2010), which is $0.0012 \mathrm{~g} \mathrm{~m}^{-3}$ according to the literature (Zhuang et al., 2004), $R$ is the exchange coefficient between the air and soil, with a value of $0.3 \mathrm{~m} \mathrm{day}^{-1}$ (Xu and Tian, 2012; Happell et al., 1995), and $f_{\text {oxi }}$ represents the fraction of $\mathrm{CH}_{4}$ oxidized through diffusion, with a value of $85 \%$ (Whalen, 2005).

\subsection{Site information and data sources}

The coastal wetlands are distributed along the southeastern coast of China (Fig. 2). Tidal marshes and mangroves are the main types of coastal wetlands in this country. Tidal marshes are usually distributed in the north of HangZhou Bay, including the tidal marshes around LiaoTung Peninsula, BoHai Sea, ShanDong Province and JiangSu Province. In the south of HangZhou Bay, e.g., Fujian Province, GuangDong Province, and HaiNan Province, the coastal wetlands are dominated by mangroves (An et al., 2007). In this study, six coastal wetlands with different latitudes from north to south were chosen, e.g., the tidal marshes from the Liao River Estuary (LR), the Yellow River Delta (YR), the YanCheng Estuary (YC), and ChongMing Island (CM), as well as the mangroves from GuangZhou city (GZ) and HaiKou city (HK) (Fig. 1 and Table 1). We measured $\mathrm{CH}_{4}$ fluxes and the synchronous air temperature, precipitation, water table depth and salinity at the YR site from July 2012 to 


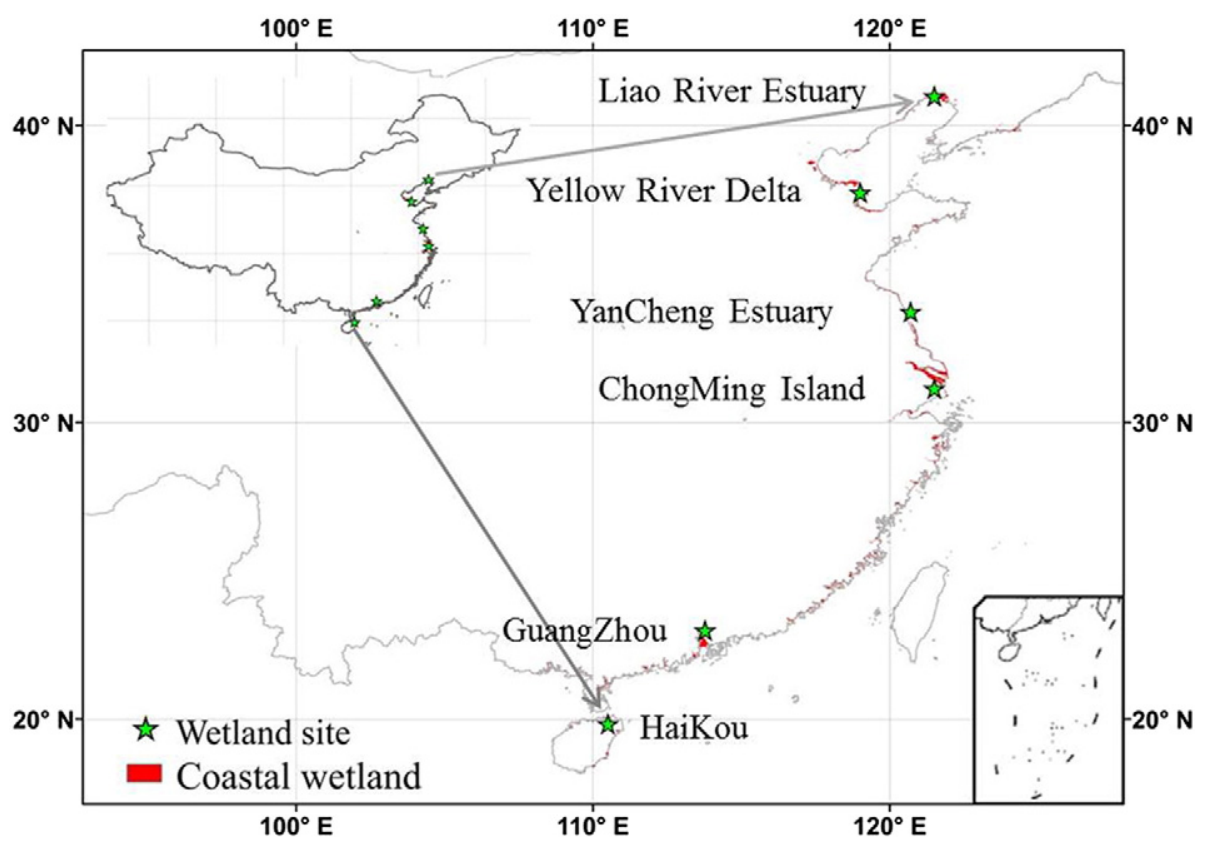

Fig. 2. Locations of the coastal wetland sites, the coastal wetland distribution map is from Niu et al. (2012).

December 2013. More details about the measurements were described in Supplementary material S1. The data for the five other coastal wetlands were obtained from previous studies and did not include synchronous measurements of salinity combined with the $\mathrm{CH}_{4}$ sampling. For these sites, we only used the average salinity to drive the model (Table 1). For the mangrove observations, the accurate timing of the measurements was not available. We could only obtain the average yearly mean $\mathrm{CH}_{4}$ emissions from the observations. For further details on the sites and measurements, please refer to Table 1 and Supplementary material S1.

At the tidal marsh sites, the total observed seasonal $\mathrm{CH}_{4}$ emissions were calculated by summing the daily fluxes. The absence of $\mathrm{CH}_{4}$ flux measurements between two adjacent days of observation was linearly interpolated. The observed total seasonal $\mathrm{CH}_{4}$ emissions from mangroves were simply calculated using the annual mean $\mathrm{CH}_{4}$ fluxes.

\subsection{Model parameterization}

The description and values of the main $\mathrm{CH}_{4} \mathrm{MOD}$ wetland parameters and inputs are shown in Table 2. Most of the parameters related to the plant species were obtained from the measurements of previous studies. For example, the fractions of aboveground and belowground to the total net primary productivity $\left(F_{\text {above }}\right.$ and $\left.F_{\text {root }}\right)$ of Phragmites, Scirpus and the mangroves were sourced from Shao et al. (1995), Chen et al. (2005) and Lin et al. (1990), respectively. Yuan et al. (2015) measured the initial concentrations of lignin and nitrogen in the plant litter $\left(L G_{0}\right.$ and $N_{0}$ ) of Phragmites and Scirpus. These two parameters were used to calculate the non-structural and structural proportion of the plant litter. Most of the soil parameters were obtained from the State Soil Survey Service of China. The fraction of plant-mediated transport $\left(T_{\text {veg }}\right)$ differs between grass species and mangroves. According to Walter and

Table 1

Site description.

\begin{tabular}{|c|c|c|c|c|c|c|}
\hline Items & $\begin{array}{l}\text { Liao River } \\
\text { Estuary } \\
(\mathrm{LR})\end{array}$ & $\begin{array}{l}\text { Yellow River } \\
\text { Delta } \\
(Y R)\end{array}$ & $\begin{array}{l}\text { YanCheng } \\
\text { Estuary } \\
(\mathrm{YC})\end{array}$ & ChongMing Island (CM) & $\begin{array}{l}\text { GuangZhou (GZ_P, GZ_N, } \\
\text { GZ_S) }\end{array}$ & $\begin{array}{l}\text { HaiKou (HK_O, } \\
\text { HK_M, } \\
\text { HK_I) }\end{array}$ \\
\hline Location & $40^{\circ} 02^{\prime} \mathrm{N}, 122^{\circ} 20^{\prime}$ & $\begin{array}{l}37^{\circ} 45^{\prime} \mathrm{N} \\
118^{\circ} 59^{\prime} \mathrm{E}\end{array}$ & $\begin{array}{l}33^{\circ} 22^{\prime} \mathrm{N} \\
120^{\circ} 42^{\prime} \mathrm{E}\end{array}$ & $31^{\circ} 15^{\prime} \mathrm{N}, 121^{\circ} 30^{\prime} \mathrm{E}$ & $23^{\circ} 01^{\prime} \mathrm{N}, 113^{\circ} 46^{\prime} \mathrm{E}$ & $19^{\circ} 51^{\prime} \mathrm{N}, 110^{\circ} 24^{\prime} \mathrm{E}$ \\
\hline Wetland type & Tidal marsh & Tidal marsh & Tidal marsh & Tidal marsh & Mangrove & Mangrove \\
\hline $\begin{array}{l}\text { Year(s) of the } \\
\text { experiment }\end{array}$ & 1997.4-1997.10 & 2012.7-2013.12 & 2012.1-2012.12 & 2004. 5-2004.12 \& 2011.2-2012.12 & 2005.3-2005.12 & 1996.1-1997.12 \\
\hline Dominant plant species & Phragmites & Phragmites & Phragmites & Scirpus & Aegiceras corniculatum etc. & Bruguiera sexangula \\
\hline $\begin{array}{l}\text { Annual air temperature } \\
\left({ }^{\circ} \mathrm{C}\right)\end{array}$ & 9 & 12.9 & 12.6 & 15.3 & 21.9 & 23.7 \\
\hline $\begin{array}{l}\text { Annual precipitation } \\
(\mathrm{mm})\end{array}$ & 625 & 590 & 1040 & 1117 & 1582 & 1940 \\
\hline Water environment ${ }^{\mathrm{c}}$ & Seasonally & Occasionally & Occasionally & Perennially & Perennially/Seasonally/Never & Never \\
\hline Average salinity (ppt) & 7.2 & 6.7 & 3.2 & 6.9 & 12.5 & $11.9^{\mathrm{d}} ; 14.2^{\mathrm{e}} ; 19.5^{\mathrm{f}}$ \\
\hline References & $\begin{array}{l}\text { Huang et al. } \\
(2005)\end{array}$ & This study & $\begin{array}{l}\text { Yuan et al. } \\
(2015)\end{array}$ & $\begin{array}{l}\text { Yang et al. (2007); Li et al. (2010b; } \\
\text { 2014) }\end{array}$ & Kang et al. (2008) & Ye et al. (2000) \\
\hline
\end{tabular}

a GZ_P, GZ_S and GZ_N are the perennially flooded microsite, seasonally flooded microsite and never flooded microsite, respectively.

b HK_O, HK_M and HK_I are the outer flat microsite, middle flat microsite and inner flat microsite, respectively.

c Perennially means always flooded during the observed period. Seasonally means that the sites are flooded during most of the observed periods, but drained for only one or two

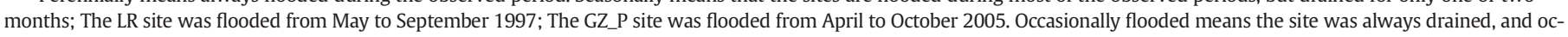
casionally flooded after the heavy rainfall events. Never flooded means that the water table was never above the ground.

d For HK_O.

e For HK_M.

${ }^{\mathrm{f}}$ For HK_I. 
Table 2

Model input and parameters.

\begin{tabular}{|c|c|c|c|c|c|c|c|c|}
\hline \multirow[t]{2}{*}{ Parameters } & \multirow[t]{2}{*}{ Description (unit) } & \multicolumn{6}{|l|}{ Value } & \multirow[t]{2}{*}{ References } \\
\hline & & LR & YR & YC & $\mathrm{CM}$ & GZ & HN & \\
\hline NPP & Net primary productivity $\left(\mathrm{g} \mathrm{m}^{-2} \mathrm{yr}^{-1}\right)$ & 2640 & 935 & 1738 & $\begin{array}{l}1570^{\$} \\
522^{\wedge}\end{array}$ & 2000 & 3000 & $\begin{array}{l}\text { Shao et al. (1995) }{ }^{1} \text {; This study }{ }^{2} \text { Y Yuan et al. }(2015)^{3} ; \text { Li et al. } \\
(2014)^{4} \text {; Lin et al. }(1990)^{5} ; \text { Kang et al. }(2008)^{6}\end{array}$ \\
\hline $\mathrm{F}_{\text {above }}{ }^{*}$ & $\begin{array}{l}\text { Proportion of above-ground/leaves to the } \\
\text { total production (dimensionless) }\end{array}$ & 0.45 & 0.45 & 0.45 & 0.45 & 0.35 & 0.35 & Shao et al. $(1995)^{1,2,3} ;$ Chen et al. $(2005)^{4} ;$ Lin et al. $(1990)^{5,6}$ \\
\hline$f_{\text {root }}$ & $\begin{array}{l}\text { Proportion of below-ground to the total } \\
\text { production (dimensionless) }\end{array}$ & 0.55 & 0.55 & 0.55 & 0.55 & 0.17 & 0.17 & Shao et al. $(1995)^{1,3,4} ;$ Chen et al. $(2005)^{2} ;$ Lin et al. $(1990)^{5,6}$ \\
\hline $\mathrm{T}_{\mathrm{veg}}$ & $\begin{array}{l}\text { The fraction of plant mediated transport was } \\
\text { available (dimensionless) }\end{array}$ & 1 & 1 & 1 & 1 & 0 & 0 & Walter and Heimann (2000) \\
\hline $\mathrm{P}_{\mathrm{ox}}$ & $\begin{array}{l}\text { The fraction of } \mathrm{CH}_{4} \text { oxidized during plant } \\
\text { mediated transport (dimensionless) }\end{array}$ & 0.9 & 0.9 & 0.9 & 0.9 & - & - & Li et al. (2015) \\
\hline VI & Vegetation index (dimensionless) & 1 & 1 & 1 & 1 & 1 & 1 & Li et al. (2015) \\
\hline SAND & Soil sand fraction (\%) & 30 & 58 & 72 & 52 & 50 & 40 & $\begin{array}{l}\text { SSSC }\left(1993^{4} ; 1994 a^{1} ; 1994 b^{6}\right) ; \text { This study }^{2} \text {; } \\
\text { Gong and Zhang }(2015)^{3} ; \text { SSSGD }(1996)^{5}\end{array}$ \\
\hline SOM & Concentration of soil organic matter $\left(\mathrm{g} \mathrm{kg}^{-1}\right)$ & 103 & 7.34 & 9.3 & 5.5 & 25.7 & 24.1 & SSSC (1996) $)^{1,5,6}$; This study ${ }^{2}$; Yuan et al. $(2015)^{3}$; Zhang et al. \\
\hline$\rho$ & Soil bulk density $\left(\mathrm{g} \mathrm{cm}^{-3}\right)$ & 0.9 & 1.27 & 1.41 & 1.06 & 1.49 & 1.52 & $(2015)^{4}$ \\
\hline $\mathrm{N}_{0}$ & $\begin{array}{l}\text { Initial concentration } \\
\text { of nitrogen in plant litter }\left(\mathrm{g} \mathrm{kg}^{-1}\right)\end{array}$ & $\begin{array}{l}12.2 \\
5.6^{\mathrm{b}}\end{array}$ & $\begin{array}{l}12.2^{\mathrm{a}} \\
5.6^{\mathrm{b}}\end{array}$ & $\begin{array}{l}12.2^{\mathrm{a}} \\
5.6^{\mathrm{b}}\end{array}$ & $\begin{array}{l}15.5 \\
11.3^{\mathrm{b}}\end{array}$ & $\begin{array}{l}9.7^{\mathrm{a}} \\
1.0^{\mathrm{b}}\end{array}$ & $\begin{array}{l}9.7^{\mathrm{a}} \\
1.0^{\mathrm{b}}\end{array}$ & $\begin{array}{l}\text { Yuan et al. }(2015)^{1,2,3,4} \text {; Gordon and Jackson }(2003)^{5,6} \text {; White } \\
\text { et al. }(2002)^{5,6}\end{array}$ \\
\hline $\mathrm{LG}_{0}$ & $\begin{array}{l}\text { Initial concentration of } \\
\text { lignin in plant litter }\left(\mathrm{g} \mathrm{kg}^{-1}\right)\end{array}$ & $\begin{array}{l}160^{\mathrm{a}} \\
166^{\mathrm{b}}\end{array}$ & $\begin{array}{l}160^{\mathrm{a}} \\
166^{\mathrm{b}}\end{array}$ & $\begin{array}{l}16^{\mathrm{a}} \\
166^{\mathrm{b}}\end{array}$ & $\begin{array}{l}207^{\mathrm{a}} \\
218^{\mathrm{b}}\end{array}$ & $\begin{array}{l}166^{\mathrm{a}} \\
246^{\mathrm{b}}\end{array}$ & $\begin{array}{l}9.7^{\mathrm{a}} \\
1.0^{\mathrm{b}}\end{array}$ & $\begin{array}{l}\text { Yuan et al. }(2015)^{1,2,3,4} \text {; Gordon and Jackson }(2003)^{5,6} \text {; Benner } \\
\text { and Hodson (1985) }\end{array}$ \\
\hline $\mathrm{Q}_{10}$ & Temperature coefficient (dimensionless) & 3.0 & 3.0 & 3.0 & 3.0 & 3.0 & 3.0 & Li et al. (2010a) \\
\hline $\mathrm{R}$ & $\begin{array}{l}\text { The exchange coefficient between the air and } \\
\text { the soil }\left(\mathrm{m} \mathrm{day}^{-1}\right)\end{array}$ & 0.3 & 0.3 & 0.3 & 0.3 & 0.3 & 0.3 & $\mathrm{Xu}(2012)$ \\
\hline
\end{tabular}

\$ For the year 2004 and 2011.

For the year 2012.

a For the aboveground litter.

b For the belowground litter.

1 For LR site.

2 For YR site.

3 For YC site.

4 For CM site.

5 For GZ site.

6 For HK site.

* $\mathrm{f}_{\text {above }}$ represents the proportion of above-ground and leaves to the total production for the herbaceous plants and trees, respectively.

Heimann (2000), trees are poor transporters compared with grass with aerenchyma. Therefore, we did not consider $\mathrm{CH}_{4}$ transportation via plants in mangroves. The vegetation index $(\mathrm{VI})$ and the fraction of $\mathrm{CH}_{4}$ oxidized during plant-mediated transport $\left(P_{o x}\right)$ have been calibrated for freshwater marshlands (Li et al., 2015); therefore, the same values were used in this study. The constant $a$ in Eq. (1) was calibrated as -0.056 by minimizing the root mean square error (RMSE) between the observed and simulated fluxes at a tidal marsh site in the Yellow River Delta (YR) from July to December 2012 (Table 1). By setting an increment of 0.001 for $a$, the model was run for all values of $a$ within the range -0.2 to 0.0 until the RMSE between the simulated and observed daily $\mathrm{CH}_{4}$ fluxes was minimized. The values and sources of the main parameters used for simulating the $\mathrm{CH}_{4}$ emissions from the different sites are presented in Table 2.

\subsection{Statistics used for model validation}

We used a set of statistical methods (Smith et al., 1996, 1997) to evaluate the improvements of the model. In addition to the linear regressions between the simulations and observations $(R)$, the RMSE, root mean deviation (RMD), model efficiency $(E F)$ and coefficient of determination $(C D)$ were used to quantify the performance of the model at the coastal wetland sites. The implications and the equations of the above statistical elements are described in Supplementary material S2.

\subsection{Model sensitivity analysis}

A sensitivity analysis was conducted to better understand the response of $\mathrm{CH}_{4} \mathrm{MOD}_{\text {wetland }}$ to the drivers in the tidal marshes and mangroves. We tested the sensitivity of a subset of the parameters in a previous study (Li et al., 2010a). In this study, the sensitivity analysis was focused on the other factors (e.g., $Q_{10}$ and $P_{o x}$ ) as well as the factors in the improved submodels (e.g., salinity and $R$ ). The sensitivity of the temperature coefficient $\left(Q_{10}\right.$ in Table 2$)$ and the salinity ( $s$ in Eq. (2) and Table 2) was tested in both the tidal marshes and the mangroves. Plant-mediated transport is the primary mechanism of $\mathrm{CH}_{4}$ emission in tidal marshes. According to previous studies, $\mathrm{CH}_{4}$ oxidation through plant transportation differs between plant species (Ström et al., 2005; Popp et al., 2000; Calhoun and King, 1997). The sensitivity of the fraction of $\mathrm{CH}_{4}$ oxidized during plant-mediated transport ( $P_{o x}$ in Table 2) was also tested for the tidal marshes. In the mangroves, we focused on the sensitivity of the exchange coefficient between the air and soil ( $R$ in Eq. (3) and Table 2). To determine model sensitivity, we ran $\mathrm{CH}_{4} \mathrm{MOD} \mathrm{D}_{\text {wetland }}$ by changing the value of one factor while holding the remaining factors constant. For example, the response of the model to $Q_{10}$ was iteratively simulated within the $Q_{10}$ range of $1.0-16.0$ (Table 3) while other factors were set to the baseline value (Table 3 ). The baseline values of $Q_{10}, P_{o x}$ and $R$ were obtained from Table 2 . We used the average value of the tidal marshes and mangroves (Table 1 ) as the baseline salinity for each wetland type (Table 3 ). The average daily air temperature, water table depth, soil sand fraction and soil organic carbon of the tidal marshes and mangroves were used when running the model for each wetland type.

\section{Results and discussion}

\subsection{Model validation}

\subsubsection{Validation of $\mathrm{CH}_{4}$ emissions from tidal marshes}

The seasonal patterns of the simulated and observed $\mathrm{CH}_{4}$ emissions from the tidal marshes dominated by Phragmites and Scripus are shown in Fig. 3. The improved $\mathrm{CH}_{4} \mathrm{MOD} \mathrm{D}_{\text {wetland }}$ model could generally simulate the seasonal changes in the $\mathrm{CH}_{4}$ fluxes from the tidal marshes of the $\mathrm{LR}$ 
Table 3

Range and baseline of the factors for model sensitivity analysis.

\begin{tabular}{|c|c|c|c|c|}
\hline Factors & Maximum & Baseline & Minimum & Reference \\
\hline Salinity & 19.5 & $6.0^{\mathrm{a}} ; 13.9^{\mathrm{b}}$ & 3.2 & This study (Table 1 ) \\
\hline $\mathrm{Q}_{10}$ & 16 & 3.0 & 1 & Dunfield et al. (1993); Westerman and Ahring (1987); Yavitt et al. (1997) \\
\hline $\mathrm{P}_{\mathrm{ox}}$ & 1.0 & $0.9^{\mathrm{a}}$ & 0.0 & Ström et al. (2005); Popp et al. (2000); Calhoun and King (1997) \\
\hline $\mathrm{R}$ & 0.63 & $0.3^{\mathrm{b}}$ & 0.18 & Happell et al. (1995) \\
\hline
\end{tabular}

a The baseline of the salinity for the herbaceous wetlands. The average salinity of the herbaceous site was used as the baseline salinity.

b The baseline of the salinity for the mangroves. The average salinity of the mangrove site was used as the baseline salinity.

site (Fig. 3a, $E F=0.34$ in Table 4), YR site (Fig. 3c, $E F=0.49$ ), YC site (Fig. 3e, $E F=0.23$ ) and $\mathrm{CM}$ site (Fig. 3g, $E F=0.56$ ).

At the LR site, peak $\mathrm{CH}_{4}$ emission occurred in late August 1997 (Fig. 3a), in accordance with a relatively higher temperature as well as the highest water table depth (Fig. 3b). However, the model did not catch the low $\mathrm{CH}_{4}$ fluxes in August and mid-September 1997 (Fig. 3a).

At the YR site, the improved model basically caught the peak emissions, i.e., in September 2012 and July 2013 (Fig. 3c), but some discrepancies were evident $(R M S E=180 \%$ in Table 4). Positive discrepancies between the modeled and observed $\mathrm{CH}_{4}$ fluxes during the two years were evident in October. In addition, the improved model did not catch some small peaks during winter, especially in December (Fig. 3c).

The simulated seasonal variation of $\mathrm{CH}_{4}$ fluxes using the improved model shows a similar trend with the observed variations at the YC site (Fig. 3e). However, the improved model systematically
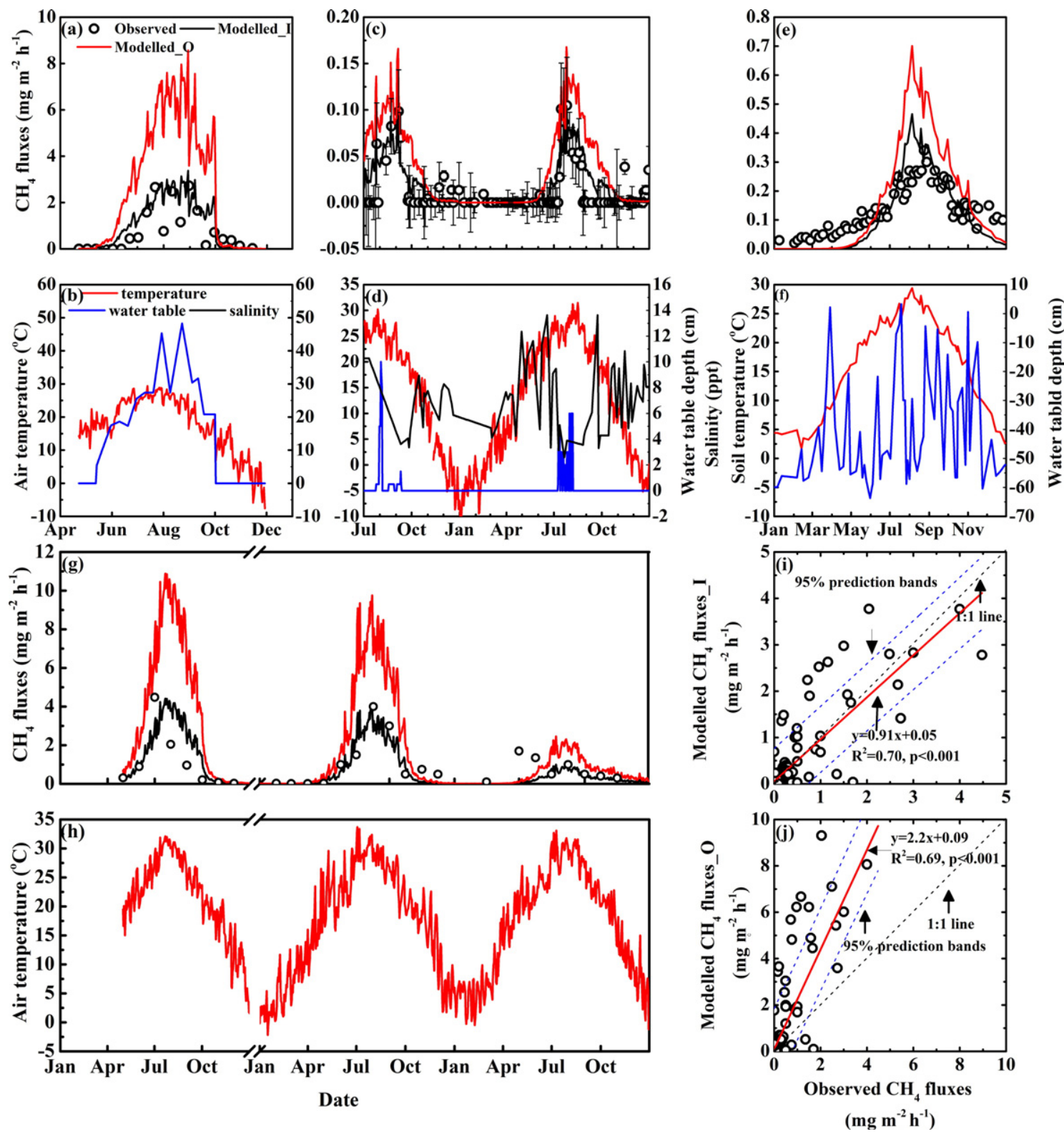

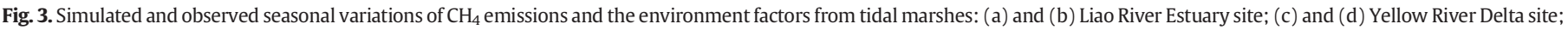

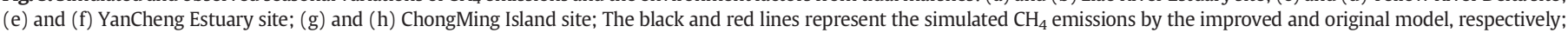
Regression of simulated against the observed $\mathrm{CH}_{4}$ fluxes from tidal marshes by the improved model (i) and the original model (j). 
Table 4

Statistical analysis of model performance on daily and seasonal $\mathrm{CH}_{4}$ emissions for different sites.

\begin{tabular}{|c|c|c|c|c|c|c|c|c|}
\hline Criteria & LR & YR & YC & $\mathrm{CM}$ & GZ & HK & All & Seasonal \\
\hline$R \_\mathrm{M}$ & 0.88 & 0.73 & 0.89 & 0.76 & 0.99 & 1.00 & 0.99 & 0.99 \\
\hline R_O & 0.71 & 0.65 & 0.89 & 0.68 & 0.98 & 1.00 & 0.99 & 0.99 \\
\hline RMSE(RMSE $95 \%) \_\mathrm{M} \%$ & $94(225)$ & $180(505)$ & $48(213)$ & $86(270)$ & $7(137)$ & $17(67)$ & $56(1102)$ & $14(164)$ \\
\hline RMSE(RMSE $95 \%) \_0 \%$ & $341(225)$ & $261(505)$ & $104(213)$ & $262(270)$ & $455(137)$ & $483(67)$ & $3128(1102)$ & $424(164)$ \\
\hline RMD_M \% & 35 & 11 & -3 & -6 & -1 & -16 & 0.41 & -2 \\
\hline RMD_O \% & 243 & 125 & 45 & 135 & 365 & 482 & 324 & 314 \\
\hline$E F \_M$ & 0.34 & 0.49 & 0.23 & 0.56 & 0.99 & 0.72 & 1.00 & 0.99 \\
\hline EF_O & -7.68 & -0.06 & -2.44 & -3.04 & -48.72 & -235.23 & -13.77 & -18.30 \\
\hline CD_M & 0.83 & 2.52 & 0.35 & 1.06 & 0.82 & 0.76 & 0.95 & 0.92 \\
\hline CD_O & 0.06 & 0.50 & 0.08 & 0.11 & 0.01 & 0.00 & 0.04 & 0.03 \\
\hline Number of samplings & 20 & 102 & 66 & 30 & 3 & 3 & 224 & 13 \\
\hline
\end{tabular}

underestimated the $\mathrm{CH}_{4}$ fluxes during both the early and late growing season, and overestimated the $\mathrm{CH}_{4}$ peak (Fig. 3e). The peak emission simulated by both the improved and original model corresponded to the highest soil temperature (Fig. 3f). However, the observed peak emission occurred approximately one month later than the simulated peaks (Fig. 3e).

The pattern of the simulated variations using the improved model generally matches the observed variations in different years at CM site dominated with Scripus (Fig. 3g). However, there was an approximate one- and two-month delay in the simulated peak emission rate when compared with the observed data from 2004 and 2012, respectively (Fig. 3g).

The regression of the simulated versus observed $\mathrm{CH}_{4}$ fluxes (Fig. 3i) resulted in an $\mathrm{R}^{2}$ value of 0.70 , a slope of 0.91 and an intercept of 0.05 ( $n=221, p<0.001)$. Although some simulated points lay outside the standard errors of the individual measured values, they fell within the 95\% confidence interval for the whole dataset (RMSE $<R M S E_{95 \%}$ in Table 4). The modified model describes the trend in the measured data better than the mean of the observations at YR site and CM site $(C D>1$ in Table 4$)$. However, if the influence of salinity was not considered, the original model could not well simulate the observations from these sites (negative $E F$ values in Table 4). The original model significantly overestimated the $\mathrm{CH}_{4}$ fluxes (Fig. 3a, c, e and g). The regression of the simulated versus observed $\mathrm{CH}_{4}$ fluxes (Fig. $3 \mathrm{j}$ ) resulted in an $\mathrm{R}^{2}$ value of 0.69 , a slope of 2.2 and an intercept of $0.09(n=221, p<0.001)$.

\subsubsection{Validation of $\mathrm{CH}_{4}$ emissions from mangroves}

The $\mathrm{CH}_{4} \mathrm{MOD}_{\text {wetland }}$ model could generally simulate the annual mean $\mathrm{CH}_{4}$ fluxes between different mangrove sites under different water table depth and salinity conditions (Fig. 4,EF>1in Table 4). The simulated annual mean $\mathrm{CH}_{4}$ fluxes increased in the sequence of the GZ_N, GZ_S and GZ_P microsites, which is in accordance with the observations (Fig. 4a). The annual mean $\mathrm{CH}_{4}$ fluxes simulated using the original model are approximately four times higher than the observed data from the GZ_S and GZ_P microsites (Fig. 4a), with a linear regression slope of 5.2 (Fig. 4c). The RMSE and RMD were significantly decreased by the improved model, i.e., from $455 \%$ to $7 \%$ and from $365 \%$ to $1 \%$, respectively (Table 4). Model efficiency was improved from -48.72 to 0.99 (Table 4).

At the $\mathrm{HK}$ site, the simulated $\mathrm{CH}_{4}$ fluxes increased as the salinity decreased, i.e., in the following order: inner flat (HK_I), middle flat (HK_M) and outer flat (HK_O) (Fig. 4b, Table 4). This is in accordance with the observed data (Fig. 4b). There were small negative discrepancies between the simulated and observed $\mathrm{CH}_{4}$ fluxes at the $\mathrm{HK}$ site when the improved model was used $(R M D=-16 \%$ in Table 4$)$. The original model could not accurately simulate the annual mean $\mathrm{CH}_{4}$ fluxes at the HK site (negative $E F$ value, $R M S E>R M S E_{95 \%}$ in Table 4). This model significantly overestimated the annual mean $\mathrm{CH}_{4}$ fluxes (Fig. $4 \mathrm{~d}$, $R M D=482 \%$ ), especially in the inner flat with the highest salinity (Fig. 4c). However, the improved model significantly increased the model $E F$, i.e., from -235.23 to 0.72 (Table 4).

\subsubsection{Comparison of simulated and observed seasonal $\mathrm{CH}_{4}$ emissions}

A comparison of the observed and modeled seasonal $\mathrm{CH}_{4}$ emissions is shown in Table 5. The improved model was able to simulate the differences in the $\mathrm{CH}_{4}$ emissions between the sites and in different years ( $E F=0.99$ in Table 4$)$. The observed seasonal $\mathrm{CH}_{4}$ emissions ranged from 0.09 to $43.44 \mathrm{~g} \mathrm{~m}^{-2}$, with an average value of $7.85 \mathrm{~g} \mathrm{~m}^{-2}$. The simulated values using the improved model ranged from 0.1 to $44.90 \mathrm{~g} \mathrm{~m}^{-2}$, with an average of $7.89 \mathrm{~g} \mathrm{~m}^{-2}$. The seasonal $\mathrm{CH}_{4}$ emissions simulated using the original model were much higher than the observed data $(R M D=314 \%$ in Table 4 ), especially at the mangrove sites, which were 4-10 times higher than the observed emissions (Table 5). Overall, the improved model significantly decreased the RMSE and $R M D$, i.e., from $424 \%$ to $14 \%$ and from $314 \%$ to $-2 \%$, and increased the $E F$ and $C D$, i.e., from -18.3 to 0.99 and from 0.03 to 0.92 , respectively (Table 4).

\subsection{Model sensitivity analysis}

The results of the sensitivity analysis are shown in Fig. 5. The model sensitivity analysis suggested that the $\mathrm{CH}_{4}$ emissions decreased exponentially with increasing $Q_{10}$ and salinity but levelled off when the $Q_{10}$ exceeded 10 (Fig. 5a and d) and the salinity exceeded 12 (Fig. 5b and e). The $\mathrm{CH}_{4}$ emissions decreased linearly with decreasing $P_{o x}$ for the tidal marshes (Fig. 5c) but increased linearly with increasing $R$ (Fig. 5f) for the mangroves. The most sensitive factor was $P_{o x}$ for the tidal marshes (Fig. $5 \mathrm{c}$ ). The $\mathrm{CH}_{4}$ emissions from the mangroves were the most sensitive to salinity (Fig. 5e). The parameter $R$ was of minor importance for the magnitude of the simulated $\mathrm{CH}_{4}$ emissions (Fig. 5f). As $Q_{10}$ increased from 1 to 16 , the $\mathrm{CH}_{4}$ emissions decreased by $85 \%$ and $62 \%$ for the tidal marshes (Fig. $5 a$ ) and mangroves (Fig. 5d), respectively. This suggests that $\mathrm{CH}_{4}$ emissions in cold areas (Fig. 5a) are more sensitive to $Q_{10}$ than in warm areas (Fig. $5 d$ ).

\subsection{Salinity impacts on $\mathrm{CH}_{4}$ simulation: importance and knowledge gap}

The influence of salinity on $\mathrm{CH}_{4}$ emissions happens widely not only in the coastal wetlands (Bartlett et al., 1987; Poffenbarger et al., 2011), but also in the saline and alkaline lakes (Joye et al., 1999; Bergier et al., 2014). The global coastal wetlands and the saline wetlands area accounts for $~ 13 \%$ of natural wetlands (Lehner and Döll, 2004). So it is important on studies concerning the salinity impacts on $\mathrm{CH}_{4}$ emissions. The salinity may decrease $\mathrm{CH}_{4}$ emissions by both limiting $\mathrm{CH}_{4}$ production and promoting $\mathrm{CH}_{4}$ oxidation. For one thing, salinity can inhibit the activities of or cause harm to methanogens, which reduces $\mathrm{CH}_{4}$ emissions (Chidthaisong and Conrad, 2000; Baldwin et al., 2006). Reducing bacteria in the sediment that accept electrons, e.g., sulfatereducing bacteria, compete with the methanogens for substrates and therefore inhibit $\mathrm{CH}_{4}$ production (van der Gon et al. 2001; Lovley and Klug, 1983). In addition to sulfate, sulfide produced during the reduction of acid sulfate in soils following flooding is also considered to inhibit 

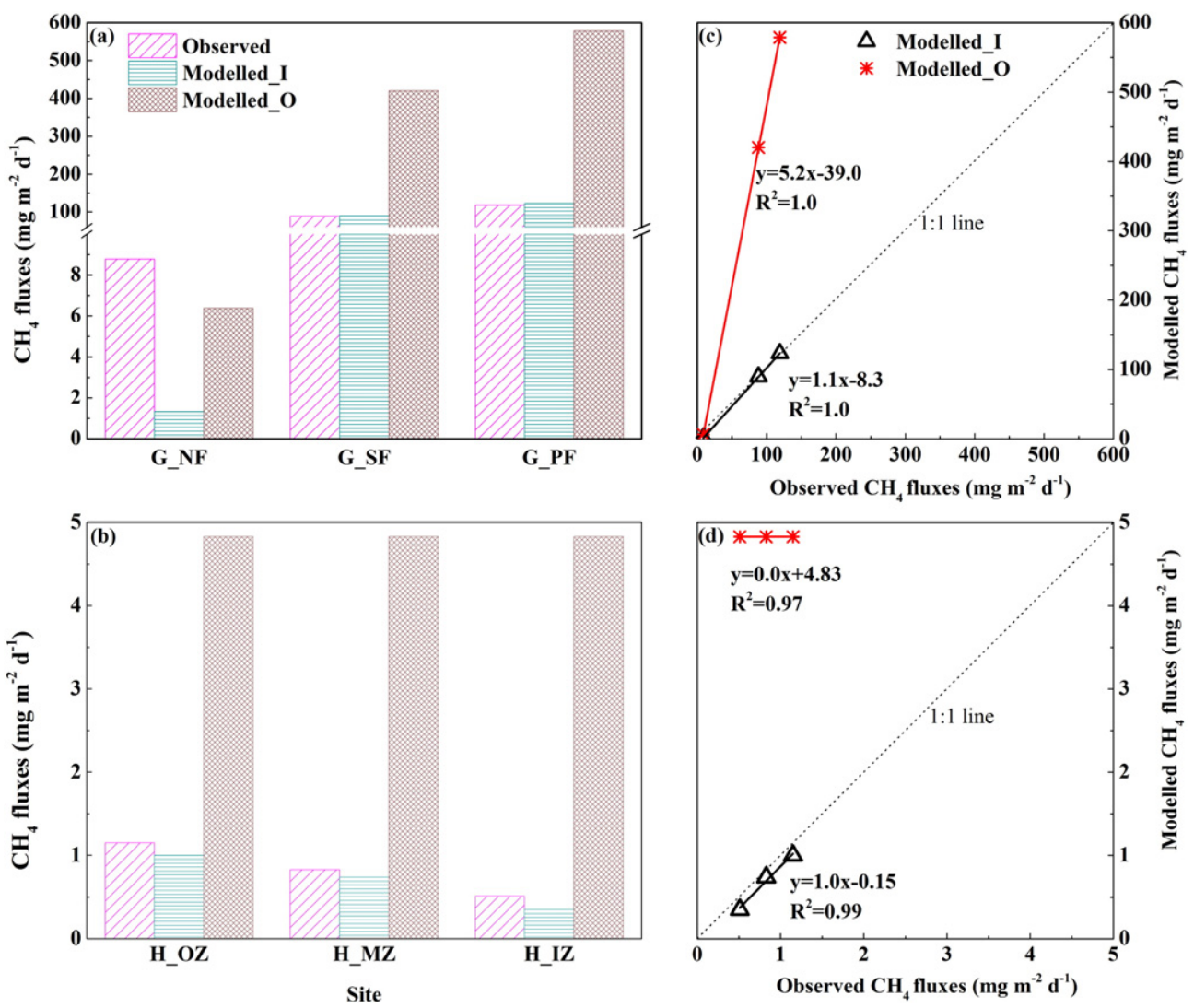

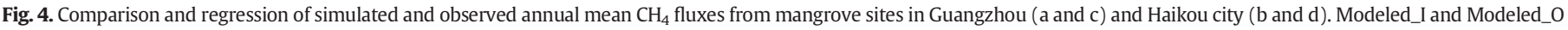
represent the simulated $\mathrm{CH}_{4}$ emissions by the modified and original model, respectively.

methanogenesis (Ramakrishnan et al., 1995). For another thing, the anaerobic oxidation of $\mathrm{CH}_{4}$ (AOM) was regarded consequential in the wetland ecosystems in recent studies (Gupta et al., 2013; Segarra et al., 2015). Evidence suggested the sulfate may stimulate AOM then reduce $\mathrm{CH}_{4}$ emissions (Eller et al., 2005; Schubert et al., 2011; Segarra et al., 2015).

The salinity impact on $\mathrm{CH}_{4}$ emissions was so important but largely regarded as in consequential in the present simulations. First, estimating regional or global $\mathrm{CH}_{4}$ emissions using a process-based model is prevalent in recent studies. However, most of the present processbased models (Cao et al., 1996; Walter et al., 1996; Potter, 1997; Zhang et al., 2002; Zhu et al., 2014; Riley et al., 2011; Wania et al., 2010; Tian et al., 2010; Xu et al., 2010) consider the influence of soil temperature, soil texture, redox potential and soil $\mathrm{pH}$, but ignore the

Table 5

Comparison of observed and modeled seasonal $\mathrm{CH}_{4}$ emissions $\left(\mathrm{g} \mathrm{m}^{-2} \mathrm{yr}^{-1}\right)$.

\begin{tabular}{llccc}
\hline Site & Period of estimation & Observation & Modeled_I $^{\mathrm{a}}$ & Modeled_O $^{\mathrm{b}}$ \\
\hline LR & $1997.4-1997.10$ & 3.81 & 4.70 & 12.97 \\
YR & $2012.7-2012.12$ & 0.09 & 0.11 & 0.23 \\
YR & $2013.1-2013.12$ & 0.13 & 0.12 & 0.24 \\
YC & $2012.1-2012.12$ & 1.09 & 0.94 & 1.41 \\
CM & $2004.5-2004.12$ & 6.52 & 8.80 & 21.88 \\
CM & $2011.1-2011.12$ & 8.29 & 7.07 & 19.50 \\
CM & $2012.1-2012.12$ & 5.05 & 2.08 & 5.49 \\
HK_O & $1996.1-1997.12$ & 0.42 & 0.37 & 1.76 \\
HK_M & $1996.1-1997.12$ & 0.30 & 0.27 & 1.76 \\
HK_I & $1996.1-1997.12$ & 0.19 & 0.13 & 1.76 \\
GZ_N & $2005.3-2005.12$ & 0.48 & 0.49 & 2.33 \\
GZ_S & $2005.3-2005.12$ & 32.19 & 32.63 & 153.39 \\
GZ_P & $2005.3-2005.12$ & 43.44 & 44.90 & 211.21 \\
\hline
\end{tabular}

a Modeled_I represents the modeled seasonal $\mathrm{CH}_{4}$ emissions by the improved model.

b Modeled_O represents the modeled seasonal $\mathrm{CH}_{4}$ emissions by the original model. influence of salinity on $\mathrm{CH}_{4}$ emissions. According to our results (Fig. 3j; Fig. 4c and d), these models may inevitably overestimate regional or global $\mathrm{CH}_{4}$ emissions (Cao et al., 1998; Petrescu et al., 2010; Melton et al., 2013; Zhu et al., 2015). For example, WETCHIMP (Wetland $\mathrm{CH}_{4}$ Inter-comparison of Models Project) determined that the global $\mathrm{CH}_{4}$ emissions from natural wetlands were $\sim 190 \mathrm{Tg}$ using the above models (Melton et al., 2013). On a global scale, the coastal wetland area accounts for $\sim 10 \%$ of natural wetlands (Lehner and Döll, 2004). If we simply assume that coastal wetlands are uniformly distributed across climatic zones, the $\mathrm{CH}_{4}$ emissions from coastal wetlands account for $19 \mathrm{Tg}$. This study shows that if a model does not consider the influence of salinity, annual mean $\mathrm{CH}_{4}$ emissions from coastal wetlands will be overestimated by $\sim 280 \%$ (Table 5 ). WETCHIMP may overestimate $\mathrm{CH}_{4}$ emissions by $14 \mathrm{Tg}$.

In addition, sea-level rise may result in greater saltwater intrusion and increased salinity in coastal wetlands (Titus, 1988), and even transform freshwater marshes near estuaries into tidal marshes in the near future (Weston et al., 2006, 2011; Herbert et al., 2015). Salinization will threaten numerous countries, including Australia, Argentina, China, the Common wealth of Independent States (former Soviet Union), India, Iran, Iraq, South Africa, Thailand and the United States of America, as well as those in Northern Africa (Bailey and James, 2000). Along with the salinity intrusion, the available sulfate radical in seawater (approximately $28 \mathrm{mmol} \mathrm{L}^{-1}$ ) will replace methanogenesis as a dominant anaerobic terminal $\mathrm{C}$ mineralization process in marine sediments and salt marsh soils (Jørgensen, 1982; Capone and Kiene, 1988). In addition, increased sulfate loading may further reduce methane fluxes by stimulating AOM (Dise and Verry, 2001; Segarra et al., 2015). Predictions of $\mathrm{CH}_{4}$ emissions from wetlands are important for the government to make policies for wetland restoration and address future climate change. The influence of salinity on $\mathrm{CH}_{4}$ emissions needs to be considered to improve the prediction of $\mathrm{CH}_{4}$ emissions. 

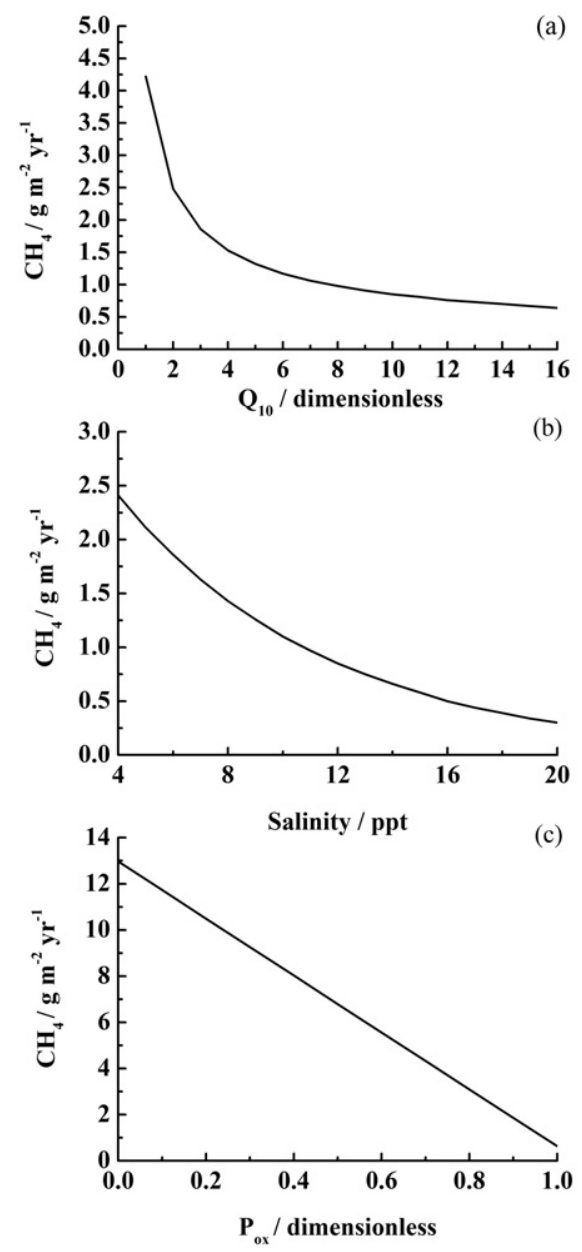
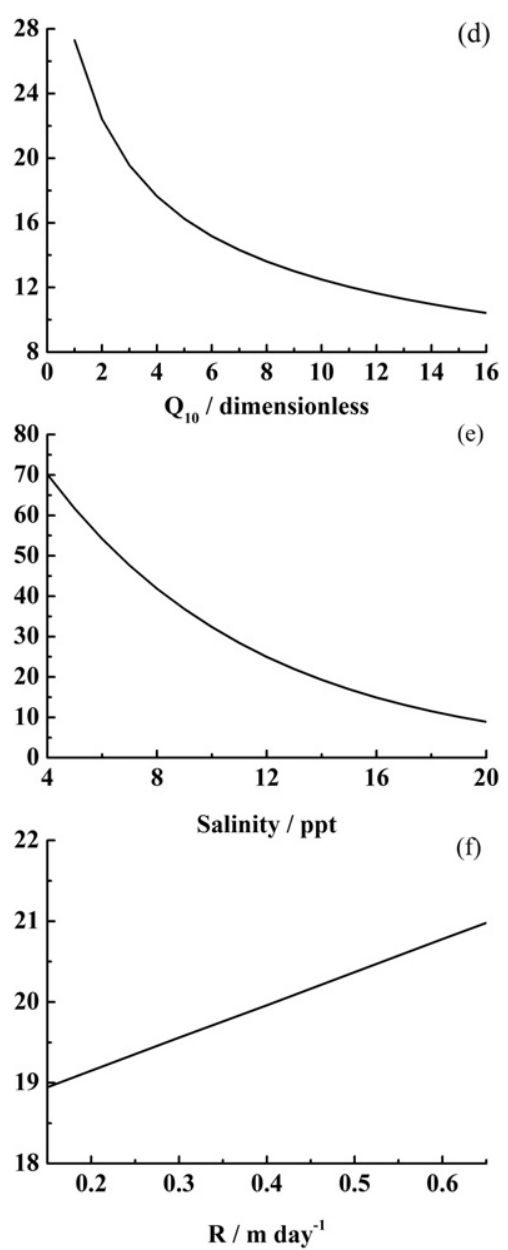

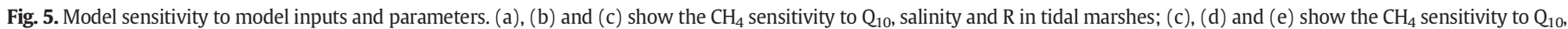
salinity and $\mathrm{P}_{\mathrm{ox}}$ in the mangroves, respectively.

Previous studies reported a negative relationship between $\mathrm{CH}_{4}$ emissions and salinity (Delaune et al. 1983; Bartlett et al. 1987). Recently, Poffenbarger et al. (2011) extended this relationship to a wider range of salinity conditions ( 0.4 to $35.1 \mathrm{ppt}$ ). In China, the salinity is within a range of 2-7 ppt for tidal marshes and 10-20 ppt for mangroves (Song et al., 1996). Therefore, it seems reasonable to adopt the relationship of Poffenbarger et al. (2011) for CH4MOD wetland to simulate $\mathrm{CH}_{4}$ emissions from China. However, the importance of salinity on methanogenesis and the methanogenic microbial population has not been studied in detail (Pattnaik et al., 2000). Salinity can influence the microbial processes of carbon cycling, but a simple non-linear regression between $\mathrm{CH}_{4}$ production and salinity cannot express this complex process. This may have resulted in the discrepancies between the simulated and observed $\mathrm{CH}_{4}$ emissions (Fig. 3, Fig. 4). A lack of observed salinity may also induce uncertainties in the $\mathrm{CH}_{4}$ simulations. For example, we used the annual mean salinity to simulate the $\mathrm{CH}_{4}$ emissions, which may induce bias between the simulated and observed values (Fig. 3a, e, g, a and b). A more detailed submodel with a mechanism to introduce the influence of different anions on methanogenesis and carbon cycling is needed in future to reduce the uncertainty in regional estimations.

\section{4. $\mathrm{CH}_{4}$ simulations in mangroves: uncertainties and future needs}

Compared with freshwater marshes, methanogenesis in and methane emissions from mangroves have been regarded as minor, both in a particular ecosystem and on a regional scale (Sotomayor et al., 1994; Giani et al., 1996; Alongi et al., 2000, 2001). In China, mangroves are estimated to cover an area of $352 \mathrm{~km}^{2}$, and are mainly distributed along the coast in Fujian, Guangdong, Guangxi, Taiwan and Hainan provinces (Zhang and Jiang, 2014). To the best of our knowledge, only Zhang and Jiang (2014) estimated $0.25 \mathrm{Gg}_{\text {of }} \mathrm{CH}_{4}$ emissions from mangroves in China by extrapolating the annual $\mathrm{CH}_{4}$ flux from the HK site (Fig. 4b). However, high $\mathrm{CH}_{4}$ emissions have also been observed in mangroves, e.g., in Guangzhou (Fig. 4a) and India (Purvaja and Ramesh, 2001). Compared with extrapolation methods, process-based models can express the complex physiological processes of plants and microorganisms that are regulated by climatic and edaphic factors. However, the mechanisms of $\mathrm{CH}_{4}$ emissions from mangroves are notoriously uncertain in the present process-based models.

First, the mechanisms of $\mathrm{CH}_{4}$ transportation and oxidation in mangroves are not as clear as in herbaceous plants. It is generally recognized that trees are poor transporters compared with herbaceous plants with aerenchyma (Hook et al., 1971; Grosse et al., 1992; Walter et al., 1996; Walter and Heimann, 2000). However, some studies have shown that mangrove pneumatophores may increase $\mathrm{CH}_{4}$ fluxes by transport through vascular channels, but this may be counter-balanced to some degree by root releases of oxygen into the rhizosphere, thereby increasing $\mathrm{CH}_{4}$ oxidation (Purvaja et al., 2004; Kitaya et al., 2002; Purnobasuki and Suzuki, 2005). Because it is difficult to quantify transportation and oxidation that occurs via pneumatophores, these processes are usually ignored in the present models. Second, according to the sensitivity analysis, $\mathrm{CH}_{4}$ emission was most sensitive to salinity in the mangroves (Fig. 5a). This relationship (Eq. (2)) was based on observed data from tidal marshes (Poffenbarger et al., 2011). A negative relationship was found for mangroves at the HK site in China (Fig. 4b); however, few 
researchers have reported a similar relationship for other mangrove studies.

In addition to the model structure, uncertainties may have arisen from the limited input data. For example, at the HN site in our study, we used the NPP of Bruguiera sexangula from another study (Lin et al., 1990) because the author did not collect NPP data (Ye et al., 2000). At the GZ site, we used the same NPP value for all of the micro sites. However, there were spatial heterogeneities in the NPP of the mangroves. This may have caused the differences between the simulated and observed $\mathrm{CH}_{4}$ fluxes (Fig. $4 \mathrm{a}$ and b).

In future, more experiments focused on both site-specific observations and the mechanisms of $\mathrm{CH}_{4}$ production, oxidation and emission in mangroves are needed. Process-based models should include the specific characteristics of $\mathrm{CH}_{4}$ processes in mangroves to accurately estimate $\mathrm{CH}_{4}$ emissions at a regional or global scale.

\section{Conclusion}

This study introduced the influence of soil salinity on $\mathrm{CH}_{4}$ emissions into a biogeophysical model, i.e., $\mathrm{CH}_{4} \mathrm{MOD}_{\text {wetland, }}$ to make it appropriate for use in coastal wetlands. The improved model can reasonably describe the observed $\mathrm{CH}_{4}$ emission variations from the tidal marshes in the Liao River Estuary, Yellow River Delta, YanCheng Estuary and ChongMing Island. In addition, the model generally simulated the difference between the annual mean $\mathrm{CH}_{4}$ fluxes from mangrove sites in GuangZhou and HaiKou city under different water table depth and salinity conditions. The improved model had a significantly lower RMSE and $R M D$ and an improved efficiency compared with the original model. However, there was bias between the simulation and observations, which may have resulted from the model structure as well as the limited observations of environmental drivers. Further improvements in its descriptive power, i.e., the detailed microbial processes influenced by salinity and the specific characteristics of $\mathrm{CH}_{4}$ transportation and oxidation in mangroves, are required to predict methane emissions more accurately from coastal wetlands.

\section{Acknowledgements}

This work was supported by the National Natural Science Foundation of China (Grant No. 31000234, 41321064 and 41175132), the Chinese Academy of Sciences (CAS) strategic pilot technology special funds (Grant No. XDA05020204 and XDA05050507) and the Climate Change Special Foundation of China Meteorological Administration (CCSF201604). We could thank the National Meteorological Information Center of the China Meteorological Administration for providing the data.

\section{Appendix A. Supplementary data}

Supplementary data to this article can be found online at http://dx. doi.org/10.1016/j.scitotenv.2016.03.186.

\section{References}

Alongi, D., Tirendi, F., Trott, L., Xuan, T., 2000. Benthic decomposition rates and pathways in plantations of the mangrove Rhizophora apiculata in the Mekong delta. Vietnam. Marine Ecol. Pro. Ser. 194, 87-101.

Alongi, D., Wattayakorn, G., Pfitzner, J., Tirendi, F., Zagorskis, I., Brunskill, G., Davidson, A. Clough, B., 2001. Organic carbon accumulation and metabolic pathways in sediments of mangrove forests in southern Thailand. Mar. Geol. 179 (1), 85-103.

An, S.Q., Li, H.B., Guan, B.H., Zhou, C.F., Wang, Z.S., Deng, Z.F., Zhi, Y.B., Liu, Y.L., Xu, C., Fang, S.B., Jiang, J.H., Li, H.L., 2007. China's natural wetlands: past problems, current status, and future challenges. Ambio 36, 335-342.

Atkinson, L.P., Hall, J.R., 1976. Methane distribution and production in the Georgia salt marsh. Estuar. Coast. Mar. Sci. 4, 677-686.

Bailey, P.C., James, K., 2000. Riverine \& Wetland Salinity Impacts-Assessment of R \& D Needs. Land and Water Resources Research and Development Corporation (Occassional Paper No. 25/99).
Baldwin, D.S., Rees, G.N., Mitchell, A.M., Watson, G., Williams, J, 2006. The short-term effects of salinization on anaerobic nutrient cycling and microbial community structure in sediment from a freshwater wetland. Wetlands 26 (2), 455-464.

Bartlett, K.B., Harriss, R.C., 1993. Review and assessment of methane emissions from wetlands. Chemosphere 26, 261-320.

Bartlett, K.B., Harriss, R.C., Sebacher, D.I., 1985. Methane flux from coastal salt marshes. J. Geophys. Res. 90, 5710-5720.

Bartlett, K.B., Bartlett, D.S., Harriss, R.C., Sebacher, D.I., 1987. Methane emissions along a salt marsh salinity gradient. Biogeochemistry 4, 183-202.

Benner, R., Hodson, R.E., 1985. Microbial degradation of the leachable and lignocellulosic components of leaves and wood from Rhizophora mangle in a tropical mangrove swamp. Mar. Ecol. Prog. Ser. 23, 221-230.

Bergier, I., Krusche, A., Guérin, F., 2014. Alkaline lake dynamics in the Nhecolândia landscape. In: Bergier, I., Assine, M.L. (Eds.), Dynamics of the pantanal wetland in South America. Springer, pp. 145-161.

Blunier, T., Chappellaz, J., Schwander, J., Stauffer, B., Raynaud, D., 1995. Variations in atmospheric methane concentration during the Holocene epoch. Nature 374, 46-49.

Bohn, T.J., Melton, J.R., Ito, A., Kleinen, T., Spahni, R., Stocker, B.D., Zhang, B., Zhu, X., Schroeder, R., Glagolev, M.V., Maksyutov, S., Brovkin, V., Chen, G., Denisov, N.S., Eliseev, A.V., Gallego-Sala, A., McDonald, K.C., Rawlins, M.A., Riley, W.J., Subin, Z.M., Tian, H., Zhuang, Q., Kaplan, J.O., 2015. WETCHIMP-WSL: intercomparison of wetland methane emissions models over West Siberia. Biogeosciences 12, 3321-3349.

Bousquet, P., Cialis, P., Miller, J. B., Dlugokencky, E. J., Hauglustaine, D. A., Prigent, C., van der Werf, G. R., Peylin, P., Brunke, E.G., Carouge, C., Langenfelds, R.L., Lathiere, J., Papa, F., Ramonet, M., Schmidt, M., Steele, L.P., Tyler, S.C., White, J., 2006. Contribution of anthropogenic and natural sources to atmospheric methane variability. Nature 443, 439-443, doi:http://dx.doi.org/10.1038/nature05132, 2006.

Calhoun, A., King, G.M., 1997. Regulation of root-associated methanotrophy by oxygen availability in the rhizosphere of two aquatic macrophytes. Appl. Environ. Microbiol. 63 (8), 3051-3058

Cao, M., Marshall, S., Gregson, K., 1996. Global carbon exchange and methane emissions from natural wetlands: application of a process-based model. J. Geophys. Res. Atmos. 101, 14399-14414.

Cao, M., Gregson, K., Marshall, S., 1998. Global methane emission from wetlands and its sensitivity to climate change. Atmos. Environ. 32 (19), 3293-3299.

Capone, D.G., Kiene, R.P., 1988. Comparison of microbial dynamics in marine and freshwater sediments: contrasts in anaerobic carbon catabolism1. Limnol. Oceanogr. 33, 725-749.

Chappellaz, J.A., Bluniert, T., Raynaud, D., Barnola, J., Schwander, J., Stauffert, B., 1993a. Synchronous changes in atmospheric $\mathrm{CH}_{4}$ and Greenland climate between 40 and 8 kyr BP. Nature 366, 443-445.

Chappellaz, J.A., Fung, I.Y., Thompson, A.M., 1993b. The atmospheric $\mathrm{CH}_{4}$ increase since the Last Glacial Maximum. Tellus B 45, 228-241.

Chen, Z., Li, B., Chen, J., 2005. Some growth characteristics and relative competitive ability of invasive Spartina alterniflora and native Scirpus mariqueter. Biodivers. Sci. 13, 130-136 (in Chinese with English abstract).

Chen, H., Zhu, Q., Peng, C.H., Wu, N., Wang, Y.F., Fang, X.Q., Jiang, H., Xiang, W.H., Chang, X. Deng, X.W., Yu, G.R., 2013. Methane emissions from rice paddies natural wetlands, lakes in China: synthesis new estimate. Glob. Chang. Biol. 19, 19-32.

Chidthaisong, A., Conrad, R., 2000. Turnover of glucose and acetate coupled to reduction of nitrate, ferric iron and sulfate and to methanogenesis in anoxic rice field soil. FEMS Microbiol. Ecol. 31 (1), 73-86.

Ciais, P., Sabine, C., Bala, G., Bopp, L., Brovkin, V., Canadell, J., Chhabra, A., DeFries, R., Galloway, J., Heimann, M., Jones, C., Quéré, C.L., Myneni, R.B., Piao, S., Thornton, P., 2013. Carbon and Other Biogeochemical Cycles. Cambridge University Press, Cambridge, United Kingdom and New York, NY, USA, pp. 465-570.

Delaune, R.D., Smith, C.J., Patrick, W.H., 1983. Methane release from Gulf Coast wetlands. Tellus B 35, 8-15.

Ding, W., Cai, Z., Wang, D., 2004. Preliminary budget of methane emissions from natural wetlands in China. Atmos. Environ. 38, 751-759.

Dise, N.B., Verry, E.S., 2001. Suppression of peatland methane emission by cumulative sulfate deposition in simulated acid rain. Biogeochemistry 53, 143-160.

Dunfield, P., Knowles, R., Dumont, R., Moore, T.R., 1993. Methane production and consumption in temperate temperate and subartic peat soils: response to temperature and pH. Soil Biol. Biochem. 25, 321-326.

Eliseev, A.V., Mokhov, I.I., Arzhanov, M.M., Demchenko, P.F., Denisov, S.N., 2008. Interaction of the methane cycle and processes in wetland ecosystems in a climate model of intermediate complexity. Izv. Atmos. Ocean. Phy. 44, 139-152.

Eller, G., Känel, L., Krüger, M., 2005. Cooccurrence of aerobic and anaerobic methane oxidation in the water column of Lake Plußsee. Appl. Environ. Microbiol. 71, 8925-8928.

Forster, P., Ramaswamy, V., Artaxo, P., Berntsen, T., Betts, R., Fahey, D., Haywood, J., Lean, J., Lowe, D., Myhre, G., Nganga, J., Prinn, R., Raga, G., Schulz, M., Van Dorland, R., 2007. Changes in atmospheric constituents and in radiative forcing. In: Solomon, S., Qin, D., Manning, M., Chen, Z., Marquis, M., Averyt, K.B., Tignor, M., Miller, H.L. (Eds.), Climate Change 2007: The Physical Science BasisContribution of Working Group I to the Fourth Assessment Report of the Intergovernmental Panel on Climate Change. Cambridge University Press, Cambridge, pp. 131-243.

Fung, I., John, J., Lerner, J., Matthews, E., Prather, M., Steele, L., Fraser, P., 1991. Threedimensional model synthesis of the global methane cycle. J. Geophys. Res. 96 (D7), 13033-13065.

Gedney, N., Cox, P.M., Huntingford, C., 2004. Climate feedback from wetland methane emissions. Geophys. Res. Lett. 31, L20503. http://dx.doi.org/10.1029/2004GL020919.

Giani, L., Bashan, Y., Holguin, G., Strangmann, A., 1996. Characteristics and methanogenesis of the Balandra lagoon mangrove soils, Baja California Sur, Mexico. Geoderma 72 (1), 149-160. 
Gong, W.M., Zhang, Z.H., 2015. Lipid biomarkers and organic matter carbon isotopes in estuarine sediments as proxies for evaluating seawater intrusion. Estuar. Coast. Shelf S. 155, 38-46.

Gordon, W.S., Jackson., R.B., 2003. Global Distribution of Root Nutrient Concentrations in Terrestrial Ecosystems. Data Set (Available on-line (http://www.daac.ornl.gov) from Oak Ridge National Laboratory Distributed Active Archive Center, Oak Ridge, Tennessee, U.S.A.) http://dx.doi.org/10.3334/ORNLDAAC/659.

Grosse, W., Frye, J., Lattermann, S., 1992. Root aeration in wetland trees by pressurized gas transport. Tree Physiol. 10, 285-295.

Gupta, V., Smemo, K.A., Yavitt, J.B., Fowle, D., Branfireun, B., Basiliko, N., 2013. Stable isotopes reveal widespread anaerobic methane oxidation across latitude and peatland type. Environ. Sci. Technol. 47, 8273-8279.

Happell, J.D., Chanton, J.P., Showers, W.J., 1995. Methane transfer across the water-air interface in stagnant wooded swamps of Florida: evaluation of mass-transfer coefficients and isotropic fractionation. Limnol. Oceanogr. 40, 290-298.

Hein, R., Crutzen, P.J., Heimann, M., 1997. An inverse modeling approach to investigate the global atmospheric methane cycle. Global Biogeochem. Cy. 11, 43-76.

Herbert, E.R., Boon, P., Burgin, A.J., Neubauer, S.C., Franklin, R.B., Ardon, M., Hopfensperger, K.N., Lamers, L.P.M., Gell, P., 2015. A global perspective on wetland salinization: ecological consequences of a growing threat to freshwater wetlands. Ecosphere 6 (10), 206. http://dx.doi.org/10.1890/ES14-00534.1.

Hook, D.D., Brown, C.L., Kormanik, P.P., 1971. Inductive flood tolerance in swamp tupelo (Nyssa sylvatica var. biflora (Walt.) Sarg.). J. Exp. Bot. 22, 78-89.

Huang, Y., Sass, R.L., Fisher, F.M., 1998. A semi-empirical model of methane emission from flooded rice paddy soils. Glob. Chang. Biol. 4, 247-268.

Huang, G.H., Li, X.Z., Hu, Y.M., Shi, Y., Xiao, D.N., 2005. Methane emission from a natural wetland of northern China. J. Environ. Sci. Health A 40, 1227-1238.

IPCC, 2013. Climate change 2013: the physical science basis. In: Stocker, T.F., Qin, D. Plattner, G.K., Tignor, M., Allen, S.K., Boschung, J., Nauels, A., Xia, Y., Bex, V., Midgley, P.M. (Eds.), Contribution of Working Group I to the Fifth Assessment Report of the Intergovernmental Panel on Climate Change. Cambridge University Press, Cambridge.

Jin, H.J., Wu, J., Cheng, G.D., Tomoko, N., Sun, G.Y., 1999. Methane emissions from wetlands on the Qinghai-Tibet Plateau. Chin. Sci. Bull. 44, 2282-2286.

Jørgensen, B.B., 1982. Mineralization of organic matter in the sea bed-the role of sulphate reduction. Nature 296, 643-645. http://dx.doi.org/10.1038/296643a0.

Joye, S.B., Connell, T.L., Miller, L.G., Oremland, R.S., Jellison, R.S., 1999. Oxidation of ammonia and methane in an alkaline, saline lake. Limnol. Oceanogr. 44, 178-188.

Kang, W.X., Zhao, Z.H., Tian, D.L., He, J.N., Deng, X.W., 2008. $\mathrm{CO}_{2}$ exchanges between mangrove and shore ecosystems and atmosphere in Guangzhou. Chin. J. Appl. Ecol. 19, 2605-2610 (in Chinese with English abstract).

Khalil, M.A.K., Shearer, M.J., Rasmussen, R.A., 1993. Methane sources in China: historical and current emissions. Chemosphere 26, 127-142.

King, G.M., Wiebe, W.J., 1978. Methane release from soils of a Georgia salt marsh. Geochimi. Cosmochim. Ac. 42, 343-348.

Kitaya, Y., Yabuki, K., Kiyota, M., Tani, A., Hirano, T., Aiga, I., 2002. Gas exchange and oxygen concentration in pneumatophores and prop roots of four mangrove species. Trees 16 (2-3), 155-158.

Lashof, D.A., Ahuja, D.R., 1990. Relative contributions of greenhouse gas emissions to global warming. Nature 344, 529-531.

Lehner, B., Döll, P., 2004. Development and validation of a global database of lakes, reservoirs and wetlands. J. Hydrol. 296, 1-22.

Li, C.S., 2000. Modeling trace gas emissions from agricultural ecosystems. Nutr. Cycl. Agroecosyst. 58, 259-276. http://dx.doi.org/10.1023/a:1009859006242.

Li, T.T., Huang, Y., Zhang, W., Song, C.C., 2010a. CH4MOD wetland: a biogeophysical model for simulating $\mathrm{CH}_{4}$ emissions from natural wetland. Ecol. Model. 221, 666-680.

Li, Y., Wang, L., Zhang, W., Zhang, S., Wang, H., Fu, X., Le, Y., 2010b. Variability of soil carbon sequestration capability and microbial activity of different types of salt marsh soils at Chongming Dongtan. Ecol. Eng. 36, 1754-1760.

Li, T.T., Huang, Y., Zhang, W., Yu, Y.Q., 2012. Methane emissions associated with the conversion of marshland to cropland and climate change on the Sanjiang Plain of northeast China from 1950 to 2100. Biogeosciences 9, 1-17.

Li, Y.J., Cheng, Z.L., Wang, D.Q., Hu, H., Wang, C., 2014. Methane emission in the process of wetland and vegetation succession in salt marsh of Yangtze River estuary. Acta Sci. Circumst. 34, 2035-2042 (in Chinese with English abstract).

Li, T.T., Zhang, W., Zhang, Q., Lu, Y.Y., Wang, G.C., Niu, Z.G., Raivonen, M., Vesala, T., 2015. Impacts of climate and reclamation on temporal variations in $\mathrm{CH}_{4}$ emissions from different wetlands in China: from 1950 to 2010. Biogeosciences 12, 6853-6868. http:// dx.doi.org/10.5194/bg-12-6853-2015.

Lin, P., Lu, C.Y., Wang, G.L., Chen, H.X., 1990. Biomass and productivity of Bruguiera sexangula mangrove forest in Hainan island, China. Journal of Xianmen University 29, 209-213 (in Chinese with English abstract).

Loulergue, L., Schilt, A., Spahni, R., Masson-Delmotte, V., Blunier, T., Lemieux, B., Barnola, J.M., Raynaud, D., Stocker, T.F., Chappellaz, J., 2008. Orbital and millennial-scale features of atmospheric $\mathrm{CH}_{4}$ over the past 800000 years. Nature 453, 383-386.

Lovley, D.R., Klug, M.J., 1983. Sulfate reducers can outcompete methanogens at freshwater sulfate concentrations. Appl. Environ. Microbiol. 45, 187-192.

Magenheimer, J.F., Moore, T.R., Chmura, G.L., Daoust, R.J., 1996. Methane and carbon dioxide flux from a macrotidal salt marsh. Bay of Fundy, New Brunswick Canada. Estuaries $19,139-145$.

Melton, J., Wania, R., Hodson, E., Poulter, B., Ringeval, B., Spahni, R., Bohn, T., Avis, C., et al., 2013. Present state of global wetland extent and wetland methane modelling: conclusions from a model intercomparison project (WETCHIMP). Biogeosciences 10 753-788.

Niu, Z.G., Zhang, H.Y., Wang, X.W., Yao, W.B., Zhou, D.M., Zhao, K.Y., Zhao, H., Li, N.N., Huang, H.B., Li, C.C., Yang, J., Liu, C.X., Liu, S., Wang, L., Li, Z., Yang, Z.Z., Qiao, F., Zheng, Y.M., Chen, Y.L., Sheng, Y.W., Gao, X.H., Zhu, W.H., Wang, W.Q., Wang, H.,
Weng, Y.L., Zhuang, D.F., Liu, J.Y., Luo, Z.C., Cheng, X., Guo, Z.Q., Gong, P., 2012. Mapping wetland changes in China between 1978 and 2008. Chin. Sci. Bull. 57, 2813-2823

Pattnaik, P., Mishra, S.R., Bharati, K., Mohanty, S.R., Sethunathan, N., Adhya, T.K., 2000. Influence of salinity on methanogenesis and associated microflora in tropical rice soils. Microbiol. Res. 155, 215-220.

Petrescu, A., Van Beek, L., Van Huissteden, J., Prigent, C., Sachs, T., Corradi, C., Parmentier F., Dolman, A., 2010. Modeling regional to global $\mathrm{CH}_{4}$ emissions of boreal and arctic wetlands. Global Biogeochem. Cy. 24, GB4009. http://dx.doi.org/10.1029/ 2009GB003610.

Poffenbarger, H.J., Needelman, B.A., Megonigal, J.P., 2011. Salinity influence on methane emissions from tidal marshes. Wetlands 31, 831-842.

Popp, T.J., Chanton, J.P., Whiting, G.J., Grant, N., 2000. Evaluation of methane oxidation in therhizosphere of a Carex dominated fen in northcentral Alberta, Canada. Biogeochemistry 51 (3), 259-281.

Potter, C.S., 1997. An ecosystem simulation model for methane production and emission from wetlands. Global Biogeochem. Cy. 11, 495-506.

Purnobasuki, H., Suzuki, M., 2005. Aerenchyma tissue development and gas-pathway structure in root of Avicennia marina (Forsk.) Vierh. J. Plant Res. 118 (4), 285-294.

Purvaja, R., Ramesh, R., 2001. Natural and anthropogenic methane emission from coastal wetlands of South India. Environ. Manag. 27 (4), 547-557.

Purvaja, R., Ramesh, R., Frenzel, P., 2004. Plant-mediated methane emission from an Indian mangrove. Glob. Chang. Biol. 10 (11), 1825-1834.

Ramakrishnan, B., Satpathy, S.N., Patnaik, P., Adhya, T.K., Rao, V.R., Sethunathan, N., 1995 Methane production in two Indian rice soils. Geomicrobiol J. 13, 193-199.

Riley, W., Subin, Z.M., Lawrence, D.M., Swenson, S.C., Torn, M.S., Meng, L., Mahowald, N.M., Hess, P., 2011. Barriers to predicting changes in global terrestrial methane fluxes: analyses using CLM4Me, a methane biogeochemistry model integrated in CESM. Biogeosciences 8 (7), 1925-1953.

Ringeval, B., Friedlingstein, P., Koven, C., Ciais, P., de Noblet-Ducoudré, N., Decharme, B. Cadule, $\mathrm{P} ., 2$ 2011. Climate- $\mathrm{CH}_{4}$ feedback from wetlands and its interaction with the climate- $\mathrm{CO}_{2}$ feedback. Biogeosciences 8 (2137-2157). http://dx.doi.org/10.5194/bg8-2137-2011.

Schubert, C.J., Vazquez, F., Lösekann-Behrens, T., Knittel, K., Tonolla, M., Boetius, A., 2011. Evidence for anaerobic oxidation of methane in sediments of a freshwater system (Lago di Cadagno). FEMS Microbiol. Ecol. 76, 26-38.

Segarra, K.E.A., Schubotz, F., Samarkin, V., Yoshinaga, M.Y., Hinrichs, K.U., Joye, S.B., 2015 High rates of anaerobic methane oxidation in freshwater wetlands reduce potential atmospheric methane emissions. Nat. Commun. 6, 7477. http://dx.doi.org/10.1038/ ncomms8477.

Seiler, W., Conrad, R., 1987. Contribution of tropical ecosystems to global budgets of trace gases, especially $\mathrm{CH}_{4}, \mathrm{H}_{2}, \mathrm{CO}$ and $\mathrm{N}_{2} \mathrm{O}$. In: Dikinson, R.E. (Ed.), The Geophysiology of Amazonia. Wiley, New York, pp. 133-140.

Shao, C., Chen, Z.L., Dong, H.D., 1995. A study on the growth and biomass of Phragmites communis in Liaohe estuary wetland. Journal of LiaoNing University 22, 89-94 (in Chinese with English abstract).

Shindell, D.T., Faluvegi, G., Koch, D.M., Schmidt, G.A., Unger, N., Bauer, S.E., 2009. Improved attribution of climate forcing to emissions. Science 326, 716-718.

Smith, J.U., Smith, P., Addiscott, T.M., 1996. Quantitative methods to evaluate and compare soil organic matter (SOM) models. In: Powlson, D.S., Smith, P., Smith, J.U. (Eds.), Evaluation of Soil Organic Matter Models Using Existing Long-Term Datasets. NATO ASI Series I 38. Springer-Verlag, Heidelberg, pp. 181-200.

Smith, P., Smith, J.U., Powlson, D.S., McGill, W.B., Arah, J.R.M., Chertov, O.G., Coleman, K Franko, U., Frolking, S., Jennkinson, D.S., Jensen, L.S., Kelley, R.H., Klein-Gunnewiek, H., Komarov, A.S., Li, C., Molina, J.A.E., Mueller, T., Parton, W.J., Thornley, J.H.M., Whitmore, A.P., 1997. A comparison of the performance of nine soil organic matter models using datasets from seven-long time experiments. Geoderma 81, 153-225.

Song, D.Q., He, J.H., Ba, F.C., Feng, Z.G., 1996. The Soil in the Coastal Zone of China. China Ocean Press, Beijing, China (in Chinese).

Song, C.C., Zhang, J.B., Wang, Y.Y., Wang, Y.S., Zhao, Z.C., 2007. Emission of $\mathrm{CO}_{2}$, $\mathrm{CH}_{4}$ and $\mathrm{N}_{2} \mathrm{O}$ from freshwater marsh in northeast of China. J. Environ. Manag. 40, 6879-6885.

Sotomayor, D., Corredor, J.E., Morell, J.M., 1994. Methane flux from mangrove sediments along the southwestern coast of Puerto Rico. Estuaries 17 (1), 140-147.

State Soil Survey Service of China (SSSSC), 1993. China Soil Series. 1. China Agriculture Press, Beijing, China, p. 491 (in Chinese).

State Soil Survey Service of China (SSSSC), 1994a. China Soil Series. 2. China Agriculture Press, Beijing, China, p. 662 (in Chinese).

State Soil Survey Service of China (SSSSC), 1994b. China Soil Series. 3. China Agriculture Press, Beijing, China, p. 402 (in Chinese).

State Soil Survey Service of GuangDong (SSSSGD), 1996. GuangDong Soil Series. China Science Press, Beijing, China, p. 417 (in Chinese).

Ström, L., Mastepanov, M., Christensen, T.R., 2005. Species-specific effects of vascular plants on carbon turnover and methane emissions from wetlands. Biogeochemistry 75 (1), 65-82

Tian, H., Xu, X., Liu, M., Ren, W., Zhang, C., Chen, G., Lu, C., 2010. Spatial and temporal patterns of $\mathrm{CH}_{4}$ and $\mathrm{N}_{2} \mathrm{O}$ fluxes in terrestrial ecosystems of North America during 1979-2008: application of a global biogeochemistry model. Biogeosciences 7 (2673-2694). http://dx.doi.org/10.5194/bg-7-2673-2010.

Titus, J.G. (Ed.), 1988. Greenhouse Effect, Sea Level Rise and Coastal Wetlands. EPA-23005-86-013. Office of Policy, Planning, and Evaluation, Washington, DC.

van der Gon, H.A.D., van Bodegom, P.M., Wassmann, R., Lantin, R.S., Metra-Corton, T.M., 2001. Sulfate-containing amendments to reduce methane emissions from rice fields: mechanisms, effectiveness and costs. Mitig. Adapt. Strateg. Glob. Chang. 6 (1), 71-89.

Walter, B.P., Heimann, M., 2000. A process-based, climate-sensitive model to derive methane emissions from natural wetlands: application to five wetland sites, sensitivity to model parameters, and climate. Global Biogeochem. Cy. 14, 745-765. 
Walter, B.P., Heimann, M., Shannon, R.D., White, J.R., 1996. A process-based model to derive methane emissions from natural wetlands. Geophys. Res. Lett. 23, 3731-3734.

Wang, M.X., Dai, A.G., Huang, J., Ren, L.X., Shen, R.X., 1993. Sources of methane in China: rice fields, agricultural waste treatment, cattle, coal mines, and other minor sources. Scientia Atmospherica Sinica 17, 52-64 (in Chinese with English abstract).

Wang, Z.P., Zeng, D., Patrick, W.H., 1996. Methane emissions from natural wetlands. Environ. Monit. Assess. 42, 143-161.

Wang, X.K., Lu, F., Yang, L., 2012. Methane emissions from China's natural wetlands: measurements, temporal variations and influencing factors. In: Lal, R., Lorenz, K., Hüttl, R.F., Schneider, B.U., von Braun, J. (Eds.), Recarbonization of the Biosphere. Springer Netherlands, pp. 99-125.

Wania, R., Ross, I., Prentice, I.C., 2010. Implementation and evaluation of a new methane model within a dynamic global vegetation model: LPJ-WHyMe v1. 3.1. Geosci. Model Dev. 3, 565-584.

Wania, R., Melton, J.R., Hodson, E.L., Poulter, B., Ringeval, B., Spahni, R., Bohn, T., Avis, C.A. Chen, G., Eliseev, A.V., Hopcroft, P.O., Riley, W.J., Subin, Z.M., Tian, H., van Bodegom, P.M., Kleinen, T., Yu, Z.C., Singarayer, J.S., Zürcher, S., Lettenmaier, D.P., Beerling, D.J. Denisov, S.N., Prigent, C., Papa, F., Kaplan, J.O., 2013. Present state of global wetland extent and wetland methane modelling: methodology of a model inter-comparison project (WETCHIMP). Geosci. Model Dev. 6 (617-641), 2013.

Wei, D., Xu, R., Tenzin, T., Dai, D.X., Wang, Y.S., Wang, Y.H., 2015. Revisiting the role of $\mathrm{CH}_{4}$ emissions from alpine wetlands on the Tibetan Plateau: evidence from two in situ measurements at 4758 and $4320 \mathrm{~m}$ above sea level. J. Geophys. Res. Biogeosci. http://dx.doi.org/10.1002/2015JG002974.

Westerman, P., Ahring, B.K., 1987. Dynamics of methane production, sulfate reduction, and denitrification in a permanently waterlogged alder swamp. Appl. Environ. Microbiol. 53, 2554-2559.

Weston, N.B., Dixon, R.E., Joye, S.B., 2006. Ramifications of increased salinity in tidal freshwater sediments: geochemistry and microbial pathways of organic matter mineralization. J. Geophys. Res. Biogeosci. 111, G01009. http://dx.doi.org/10.1029/ 2005JG000071.

Weston, N.B., Vile, M.A., Neubauer, S.C., Velinsky, D.J., 2011. Accelerated microbial organic matter mineralization following salt-water intrusion into tidal freshwater marsh soils. Biogeochemistry 102, 135-151.

Whalen, S.C., 2005. Biogeochemistry of methane exchange between natural wetlands and atmosphere. Environ. Eng. Sci. 22, 73-94.

White, M.A., Thornton, P.E., Running, S.W., Nemani., R.R., 2002. Literature-derived Parameters for the BIOME-BGC Terrestrial Ecosystem Model. Data Set (Available on-line (http://www.daac.ornl.gov) from Oak Ridge National Laboratory Distributed Active Archive Center, Oak Ridge, Tennessee, U.S.A.) http://dx.doi.org/10.3334/ ORNLDAAC/652.
Xu, X.F., Tian, H.Q., 2012. Methane exchange between the marshland and the atmosphere over China during 1949-2008. Global Biogeochem. Cy. 26. http://dx.doi.org/10.1029/ 2010GB003946.

Xu, X.F., Tian, H.Q., Zhang, C., Liu, M.L., Ren, W., Chen, G.S., Lu, C.Q., Bruhwiler, L., 2010. Attribution of spatial and temporal variations in terrestrial methane flux over North America. Biogeosciences 7, 3637-3655. http://dx.doi.org/10.5194/bg-7-3637-2010.

Yang, H.X., Wang, D.Q., Chen, Z.L., Cheng, H., Wang, J., Xu, S.Y., Yang, L.Y., 2007. Seasonal variation of $\mathrm{CH}_{4}$ emission from Chongming east intertidal flat of Yangtze River Estuary. Scientia Geogr Aphica Sinca 27, 408-413 (in Chinese with English abstract).

Yavitt, J.B., Williams, C.J., Wieder, R.K., 1997. Production of methane and carbon dioxide in peatland ecosystems across North America: effects of temperature, aeration, and organic chemistry of peat. Geomicrobiol J. 14, 299-316.

Ye, Y., Lu, C.Y., Lin, P., 2000. $\mathrm{CH}_{4}$ dynamics in sediments of Bruguiera sexangula mangrove at Hegang estuary. Soil Environ. Sci. 9, 91-95 (in Chinese with English abstract).

Yuan, J. D. Ding W.X. Liu, D.Y, Kang H., Freeman, C. Xiang J. Lin, YX, 2015. Exotic Spartina alterniflora invasion alters ecosystem-atmosphere exchange of $\mathrm{CH}_{4}$ and $\mathrm{N}_{2} \mathrm{O}$ and carbon sequestration in a coastal salt marsh in China. Glob. Chang. Biol. 21, 1567-1580. http://dx.doi.org/10.1111/gcb.12797.

Zhang, X., Jiang, H., 2014. Spatial variations in methane emissions from natural wetlands in China. Int. J. Environ. Sci. Technol. 11 (1), 77-86.

Zhang, Y., Li, C.S., Trettin, C.C., Li, H., Sun, G., 2002. An integrated model of soil, hydrology, and vegetation for carbon dynamics in wetland ecosystems. Global Biogeochem. Cy. 16, 1061. http://dx.doi.org/10.1029/2001gb001838.

Zhang, T.Y., Ge, Z.M., Zhang, L.Q., Chen, H.P., Yan, G., 2015. Influence of salt marsh vegetation and sedimentation on the distribution of soil carbon and nitrogen in the Chongming Dongtan wetlands. Acta Sci. Circumst. 35, 836-843. http://dx.doi.org/ 10.13671/j.hjkxxb.2014.0772.

Zhu, Q., Liu, J., Peng, C., Chen, H., Fang, X., Jiang, H., Yang, G., Zhu, D., Wang, W., Zhou, X., 2014. Modelling methane emissions from natural wetlands by development and application of the TRIPLEX-GHG model. Geosci. Model Dev. 7, 981-999.

Zhu, Q., Peng, C.H., Chen, H., Fang, X.Q., Liu, J.X., Jiang, H., Yang, Y.Z., Yang, G., 2015. Estimating global natural wetland methane emissions using process modelling: spatiotemporal patterns and contributions to atmospheric methane fluctuations. Glob. Ecol. Biogeogr. 24 (8), 959-972.

Zhuang, Q.L., Melillo, J.M., Kicklighter, D.W., Prinn, R.G., McGuire, A.D., Steudler, P.A., Felzer, B.S., Hu, S., 2004. Methane fluxes between terrestrial ecosystems and the atmosphere at northern high latitudes during the past century: a retrospective analysis with a process-based biogeochemistry model. Global Biogeochem. Cy. 18, GB3010. http://dx.doi.org/10.1029/2004GB002239. 